(C) 1989 ISIJ

技術資料

最近のレーザー加工技術の進展

\title{
Progress in Laser Materials Processing
}

\author{
Muneharu KUTSUNA
}

\section{1.はじめに}

レーザー (LASER : Light Amplification by Stimulated Emission of Radiation) はその発生のメカニズム から「量子機械」と呼ばれ, 現代の先端技術の一角を占 めている，その発展過程を表 $1^{1)}$ に示すが，その端緒は 1900 年のマックス・プランクによる「エネルギーの量子
仮説」及び 1916 年のアインシュタインの「量子論によ る輻射の放出と吸収 (誘導放出の仮陔)」にまでさかの ぼることができる．C.H. ToWNAs 教授の MASERの着 想まで数 10 年を要するが, 1960 年に T. H. MAIMAN が ルビーレーザーを発振して以来，レーザー科学技術は約 25 年間に急速に発展した。レーザー光のもつ単色性(そ れぞれのレーザーは固有の単一波長をもつ), 干涉性(位

表 1 レーザー科学技術の発展

\begin{tabular}{|c|c|c|c|c|}
\hline \multirow{2}{*}{1900} & \multicolumn{2}{|r|}{ レーザー科学の発達 } & \multicolumn{2}{|r|}{ レーザー加工技術の発達 } \\
\hline & 1900 & $\begin{array}{l}\text { ーマックスプランク:「エネルギ } \\
\text { 一の量子仮説」 } \\
\text { —アインシタイン:星子論によ } \\
\text { る輻射の放出と吸収」(「誘導 } \\
\text { 放出」の仮説) }\end{array}$ & & \\
\hline 1950 & $\begin{array}{r}-1951 \\
1954 \\
1957\end{array}$ & $\begin{array}{c}\text { 4-C.H.Townes:マイクロ波に } \\
\text { よるMASERの着想 } \\
\text { 5一C.H.TownEs:米物理学会誌 } \\
\text { に「分子マイクロ波発振器 } \\
\text { (MASER)」を発表 } \\
\text { 4一西沢潤一:「半道体メーザ」 } \\
\text { の特許出願 }\end{array}$ & & \\
\hline 1960 & $\begin{array}{r}-1960 \\
1960 \\
1961 \\
1964 \\
1964 \\
1966 \\
1969\end{array}$ & 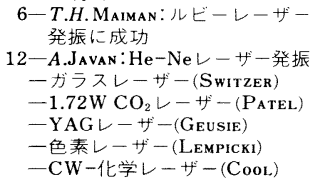 & $\begin{array}{l}1965 \\
1967\end{array}$ & $\begin{array}{l}\text { 一ダイヤモンドの穴あけにルビーレーザー } \\
\text { が使われた。 } \\
\text {-8kWCO } 2 \text { レーザー装置 (Raytheon社) }\end{array}$ \\
\hline 1970 & $\begin{array}{r}-1970 \\
1972\end{array}$ & $\begin{array}{l}\text { 一液体Xeより紫外レーザー } \\
\text { 発振 (D.G.BASov) } \\
\text { 一エシマーレーザー } \\
\text { (J.J.ユーイング) }\end{array}$ & $\begin{array}{l}1970 \\
1972\end{array}$ & $\begin{array}{l}\text { 一高速流型 } \mathrm{CO}_{2} レ \text { ザー(Deutch, Tiffany) } \\
\text { 一環流型 } 20 \mathrm{~kW} \mathrm{CO} \mathrm{CO}_{2} レ \text { ザー開発 (UTRC 社) }\end{array}$ \\
\hline & 1976 & $\begin{array}{l}\text {-X線リゾグラフィー(SOR) } \\
\text { の実験(IBM) }\end{array}$ & 1973 & $\begin{array}{l}\text { - } 10 \mathrm{~kW} \text { 級 } \mathrm{CO}_{2} レ \text { ザー市販 }(\mathrm{AVCO} \text { 社) } \\
\text { 一自動車ギアハウジング焼入れ }(\mathrm{GM} \text { 社) } \\
\text { 一ディーゼルエンジンシリンダーライナーの } \\
\text { 焼入れ(GM社) }\end{array}$ \\
\hline 1080 & $\mathrm{~L}$ & & $\begin{array}{l}1977 \\
(\sim 1985)\end{array}$ & $\begin{array}{l}\text { 一「超高性能レーザ一応用複合生産システム」 } \\
\text { (日本, 通産省大型ブロジェクト) }\end{array}$ \\
\hline 1700 & & & $\begin{array}{l}1981 \\
1983\end{array}$ & $\begin{array}{l}\text { 一製鋼ラインのコイルの突合わせ溶接にレー } \\
\text { 一ザー適用(川崎製鉄) } \\
\text { 一レーザー切断 CAD/CAM システム稼動(東芝) }\end{array}$ \\
\hline & & & $\begin{array}{l}1984 \\
1985 \\
1987 \\
1988\end{array}$ & 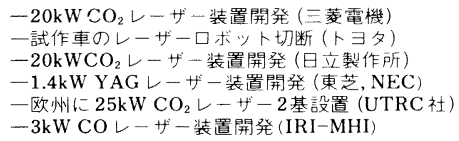 \\
\hline
\end{tabular}

昭和 63 年 11 月 22 日受付 (Received Nov. 22, 1988) (依頼技術資料)

* 名古屋大学工学部講師 工博 (Faculty of Engineering, Nagoya University, Furo-cho Chikusa-ku Nagoya 464-01) Key words: laser materials processing ; laser facility ; laser welding ; laser cutting ; laser drilling ; laser marking ; laser surface processing ; laser application ; $\mathrm{CO}_{2}$ laser ; YAG laser. 
相のそろつた電磁波である)，指们性（ビームは拡がり 角度が数 $\mathrm{m} \mathrm{rad}$ と小さく，直進性大)，集光性（光学系 により集光した際の最小ビーム径は波言の約 10 倍程度 である) 及び, 高エネルギー密度性 (焦点でのエネルギー 密度が $10^{6} \sim 10^{12} \mathrm{~W} / \mathrm{cm}^{2}$ にも高められる）などの特性 を有しており，表 2 に示すように多岐にわたつてレー ザー技術が利用されている.光ファイバー,レーザーディ スク，レーザーメス，レーザー計測器，レーザー加工機 などは身近なものとなつている。これら応用はますます

表 2 レーザー技術の忍用分野

\begin{tabular}{|c|c|c|}
\hline レーザー特性 & 到㨄技術 & 対象 分 野 \\
\hline $\begin{array}{l}\text { 単色 性 } \\
\text { F涉 性. }\end{array}$ & $\begin{array}{l}\text { 通 信 } \\
\text { 測 } \\
\text { 情報処理 } \\
\text { 光化 } \\
\text { そ } \\
\text { 学 }\end{array}$ & 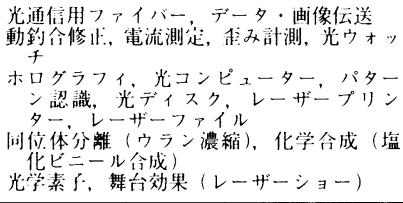 \\
\hline & 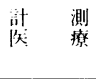 & 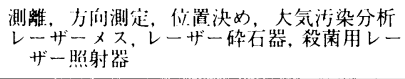 \\
\hline 指们性 & 材料加 I: & $\begin{array}{l}\text { 溶接・接仓 } \\
\text { 除去加 I: } \\
\text { 表牦加 } \mathrm{I} \\
\text { 新材料の製造, 破碀, 板曲げなど }\end{array}$ \\
\hline (エネルギー源) & $\begin{array}{l}\text { 审. } \\
\text { 核融众 } \\
\text { そ } \\
\text { 他 }\end{array}$ & $\begin{array}{l}\text { ミサイル誘導, レーザーレーダー, 起爆, } \\
\text { 熱兵器 } \\
\text { 電伀送, プラズマ生成, 高温高性生成 }\end{array}$ \\
\hline
\end{tabular}

拡大されている．本題であるレーザー加I技術分野につ いて具体的な応用例, 研究例を表 3 に示す. 大別すると 溶接·接合, 除去加工, 表面加工（加熱, 溶融, 蒸発, 化学反応プロセス）などがあり，更に新しい利用法が研 究開発されている。電気・電子機器産業, 自動車産業, 鉄鋼業はじめ，たばこ産業や食品産業においても，金属 から布に至るまで, 幅広くレーザー加汇が普及してきた。

\section{2. 各種加工用レーザー機器}

加工に用いられる主なレーザーの種類と特性を表 4 に 示す。材料加】には $\mathrm{CO}_{2}$ レーザーおよび YAG $\left(\mathrm{Y}_{3} \mathrm{Al}_{5} \mathrm{O}_{12}\right.$ 結晶体) レーザーが主に利用されている。最

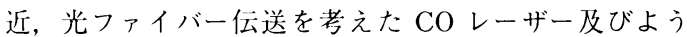
素レーザー，あるいは紫外線領域の波長をもつエキシ マーレーザーなどが開発され，その加工特性が明らかに されつつある。

\section{$2 \cdot 1$ ( $(0,2$ レーザー加工装置}

レーザー出力 $500 \mathrm{~W}$ 以上の加Iには主に $\mathrm{CO}_{2}$ レー ザーが用いられている．大出力化が可能であり， $25 \mathrm{~kW}$ の装置も市販されている，研究用にはUTRC (United Technology Research Center, 米国) で $77 \mathrm{~kW}$ が開発さ れている．我が国では通産省の大型プロジェクトで 20 $\mathrm{kW}$ が開発されている。これらはレーザー光軸方向，ガ ス流方向及び放電方向により表 $5^{2)}$ に示すように分類さ れる。同軸形は放電空間が大きくないので多重折り返し

表 3 レーザー加工.法の種類とその用途

\begin{tabular}{|c|c|c|c|c|}
\hline \multicolumn{4}{|c|}{ 加1\%種数 } & 主な適用分野·目的 \\
\hline $\begin{array}{c}\text { 溶 } \\
\text { 接接 } \\
\text { 点. }\end{array}$ & \multicolumn{3}{|c|}{ 溶接 } & 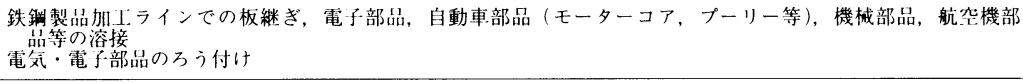 \\
\hline $\begin{array}{c}\text { 除 } \\
\text { 志 } \\
\text { 驾 } \\
\text { L. }\end{array}$ & \multicolumn{3}{|c|}{$\begin{array}{l}\text { 切断 } \\
\text { 穴あけ } \\
\text { 微細除去加1: } \\
\text { マーキンク・版刻 } \\
\text { 溶融切削成形 } \\
\text { クリーニング }\end{array}$} & 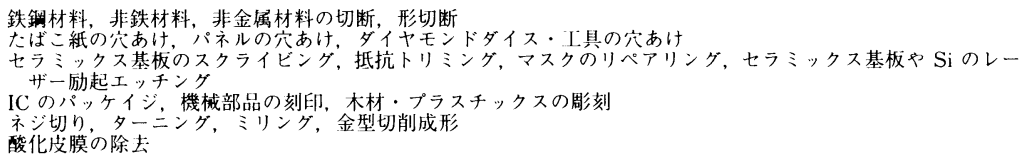 \\
\hline \multirow{5}{*}{$\begin{array}{l}\text { 表 } \\
\text { 面 } \\
\text { 加 } \\
\text { 1: }\end{array}$} & $\begin{array}{l}\text { 口加 } \\
\text { 七熱 } \\
\text { スプ }\end{array}$ & \multicolumn{2}{|c|}{ 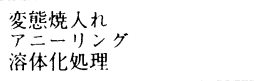 } & 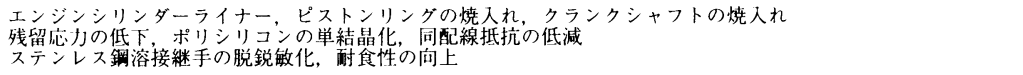 \\
\hline & \multirow{2}{*}{$\begin{array}{l}\text { 溶 } \\
\text { 融 } \\
フ^{\circ} \\
\square \\
t \\
\text { z }\end{array}$} & \multicolumn{2}{|c|}{ 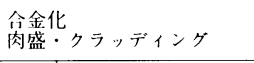 } & 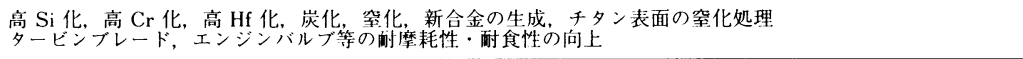 \\
\hline & & & 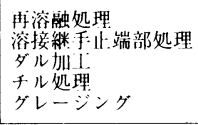 & 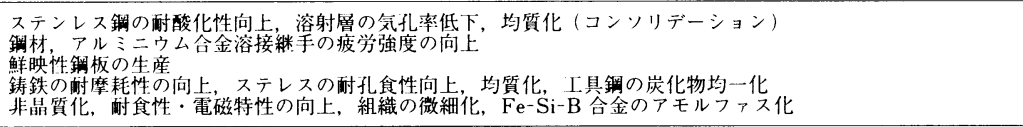 \\
\hline & $\begin{array}{l}\text { 口暴 } \\
\text { 七発 } \\
\text { スプ }\end{array}$ & \multicolumn{2}{|c|}{$\begin{array}{l}\text { レーザーPVD } \\
\text { 磁メ細分化処理 } \\
\text { 衝整硬化 } \\
\text { 乾燥処理 }\end{array}$} & 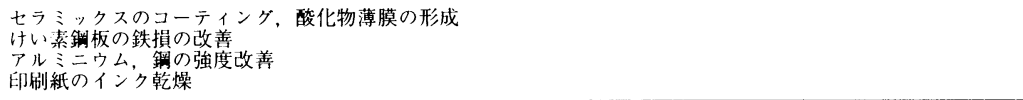 \\
\hline & $\begin{array}{l}\text { 华 } \\
\text { 学 } \\
\text { 坚 } \\
\text { 笖 }\end{array}$ & \multicolumn{2}{|c|}{$\begin{array}{l}\text { レーザーCVD } \\
\text { レーザー光化学: } \\
\text { レーザーリソグラフィ } \\
\text { めつき加速処理. }\end{array}$} & 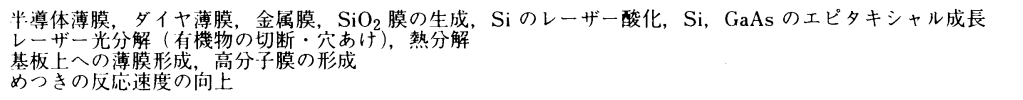 \\
\hline $\begin{array}{l}\xi \\
\text { の } \\
\text { 他 }\end{array}$ & \multicolumn{3}{|c|}{$\begin{array}{l}\text { 新材料の製造 } \\
\llcorner\text { ザー援切削成形 } \\
\text { 曲げ加 I. } \\
\text { 割断, 破砕 }\end{array}$} & 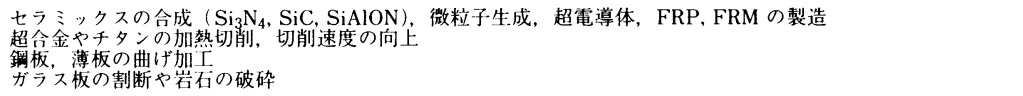 \\
\hline
\end{tabular}


表 4 各種加工用レーザーの特性と波長スペクトル

\begin{tabular}{|c|c|c|c|c|c|c|c|}
\hline & レーザーの種類 & $\begin{array}{l}\text { レーザー } \\
\text { 光の波長 } \\
(\mu \mathrm{m})\end{array}$ & $\begin{array}{c}\text { パルス幅 } \\
(\mathrm{s})\end{array}$ & $\begin{array}{l}\text { 発振 } \\
\text { 赇式 }\end{array}$ & $\begin{array}{l}\text { 平均 } \\
\text { 出力 }\end{array}$ & 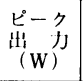 & 效 \\
\hline \multirow{3}{*}{$\begin{array}{l}\text { 固 } \\
\text { 体 } \\
2 \\
1 \\
+゙ \\
+1\end{array}$} & ルビー & 0.6943 & $\begin{array}{c}10^{-3} \sim \\
10^{-8} \\
-\end{array}$ & $\begin{array}{l}\text { パル } \\
\mathrm{Q}_{\mathrm{SW}} \\
\mathrm{CW}\end{array}$ & $\begin{array}{c}\frac{m \mathrm{~W}}{-} \\
0.01 \mathrm{~W}\end{array}$ & $\begin{array}{l}10^{6} \\
10^{10} \\
10^{-1}\end{array}$ & $0.1 \%$ \\
\hline & $\begin{array}{l}\text { アレレキサンド } \\
\text { ライト }\end{array}$ & $\begin{array}{l}0.7 \text { - } 0.815 \\
\text { (波長可変) }\end{array}$ & $\begin{array}{c}10^{-1} \sim \\
10^{-7} \\
\end{array}$ & $\begin{array}{l}\text { パルス } \\
\text { Qsw }\end{array}$ & $150 \mathrm{~W}$ & - & $3 \sim 5 \%$ \\
\hline & $\mathrm{Nd}: \mathrm{YAG}$ & 1.06 & $\begin{array}{c}10^{2} \sim \\
10^{-8}\end{array}$ & $\begin{array}{l}\text { パルス } \\
\text { QsW } \\
\text { CW }\end{array}$ & $\begin{array}{c}400 \mathrm{~W} \\
1.8 \mathrm{~kW}\end{array}$ & $\begin{array}{l}10 \\
10^{5} \\
10^{4}\end{array}$ & $3 \sim 5 \%$ \\
\hline \multirow{4}{*}{$\begin{array}{c}カ ゙ \\
\text { ス } \\
レ \\
1 \\
+゙ \\
1\end{array}$} & $\begin{array}{r}\mathrm{ArF} \\
\text { エキシマー } \mathrm{KrF} \\
\mathrm{XeCl} \\
\mathrm{XeF}\end{array}$ & $\begin{array}{l}0.193 \\
0.249 \\
0.308 \\
0.350\end{array}$ & $10^{-5} \sim \times 10^{-4}$ & パルス & $100 \mathrm{~W}$ & $\begin{array}{l}0^{3} \\
- \\
10^{8}\end{array}$ & $1 \sim 4 \%$ \\
\hline & よう素レーザー & 1.3 & - & $\mathrm{CW}$ & $1000 \mathrm{~W}$ & - & $\begin{array}{c}\text { 化学効榇 } \\
40 \%\end{array}$ \\
\hline & CO レーザー & $4.2 \sim 8.2$ & - & $\mathrm{CW}$ & $3000 \mathrm{~W}$ & - & $27 \%$ \\
\hline & $\mathrm{CO}_{2}$ レーザー & 10.6 & $10^{-4} \sim 1$ & $\begin{array}{l}\text { パルス } \\
\mathrm{CW}\end{array}$ & $\begin{array}{l}1000 \mathrm{~W} \\
25 \mathrm{~kW} \\
(77 \mathrm{~kW})\end{array}$ & - & $10 \sim 20 \%$ \\
\hline
\end{tabular}

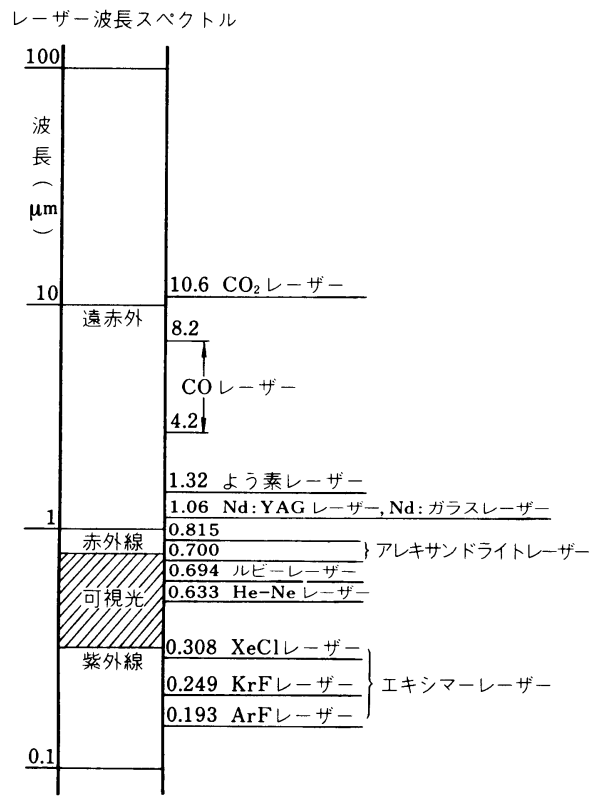

表 $5 \mathrm{CO}_{2}$ レーザー装置の放電チャネルによる分類とその例 ${ }^{2)}$

\begin{tabular}{|c|c|c|c|c|c|c|c|c|c|}
\hline & \multirow{3}{*}{$\begin{array}{l}\text { レーザー光軸方向 } \\
(X \text { 方向る等る }\end{array}$} & \multirow{3}{*}{ ガス流方向 } & \multirow{3}{*}{ 放電方向 } & & 罱 & 例 & & \\
\hline & & & & & \multirow{2}{*}{$x-$ - } & \multirow{2}{*}{ 放電 $f_{j}$ 式 } & \multicolumn{3}{|c|}{ 放 電 条 件 } \\
\hline & & & & & & & ガス & 流 & ギャップ \\
\hline \multirow{5}{*}{ 型 } & \multirow{5}{*}{$\begin{array}{l}\text { 同軸型 (Coaxial) } \\
\text { たは軸流型 } \\
\text { (Axial-flow) }\end{array}$} & \multirow{5}{*}{$X$ 方向 } & \multirow{5}{*}{$X$ 方向 } & \multirow{5}{*}{$X$ 方向 } & $\begin{array}{l}\text { Photon Sources } \\
(1 \mathrm{~kW})\end{array}$ & \multirow{4}{*}{ 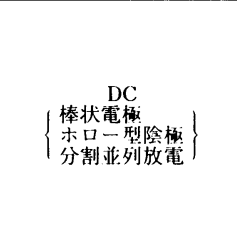 } & $\begin{array}{c}20 \sim 30 \\
\text { torr }\end{array}$ & (低流速) & $\geqq 1.5 \mathrm{~m}$ \\
\hline & & & & & $\begin{array}{c}\text { Control Laser } \\
(2 \mathrm{~kW}) \\
\text { BOC }(2 \mathrm{~kW})\end{array}$ & & $\begin{array}{l}40 \sim 45 \\
\text { torr }\end{array}$ & $\begin{array}{l}>100 \mathrm{~m} / \mathrm{s} \\
\text { (高流速) }\end{array}$ & $\sim 1 \mathrm{~m}$ \\
\hline & & & & & ダイ ヘ ン & & $\begin{array}{c}80-140 \\
\text { torr }\end{array}$ & $>200 \mathrm{~m} / \mathrm{s}$ & $70 \mathrm{~cm}$ \\
\hline & & & & & Messer Griesheim & & 40 torr & $>100 \mathrm{~m} / \mathrm{s}$ & $\sim 80 \mathrm{~cm}$ \\
\hline & & & & & Rofin Sinar & $\mathrm{RF}(27 \mathrm{MHz})$ & - & - & - \\
\hline & $\begin{array}{l}\text { 螺線ガス流型 } \\
\text { (Turbo-flow) }\end{array}$ & $X$ 方向 & 螺線 $X$ 方向 & $X$ 方向 & $\begin{array}{c}\text { Photon Sources } \\
(3.5 \mathrm{~kW})\end{array}$ & $\mathrm{DC}$ & - & 高流速 & $\sim 1 \mathrm{~m}$ \\
\hline \multirow{2}{*}{\multicolumn{2}{|c|}{2 軸直交型 (Cross beam) }} & \multirow[b]{2}{*}{$X$ 方向 } & \multirow[b]{2}{*}{$Y$ 方向 } & \multirow[b]{2}{*}{ 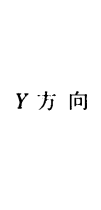 } & $(1 \sim 10 \mathrm{~kW})$ & DC & $\begin{array}{c}35-40 \\
\text { torr }\end{array}$ & $>100 \mathrm{~m} / \mathrm{s}$ & $\sim 50 \mathrm{~cm}$ \\
\hline & & & & & $\begin{array}{l}\text { UTRC } \\
(27 \mathrm{~kW})\end{array}$ & 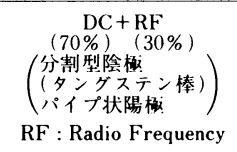 & 30 torr & $130 \mathrm{~m} / \mathrm{s}$ & $65 \mathrm{~cm}$ \\
\hline \multirow{4}{*}{\multicolumn{2}{|c|}{$\begin{array}{l}3 \text { 軸直交型 (Cross flow) } \\
\text { た は 環 流型 (Trans- } \\
\text { vesre flow) }\end{array}$}} & \multirow{4}{*}{$X$ 方向 } & \multirow{4}{*}{$Y$ 方向 } & \multirow{4}{*}{$Z$ 方向 } & $\begin{array}{l}\text { Culham Inst. } \\
(11 \mathrm{~kW})\end{array}$ & $\mathrm{DC}$ & $\begin{array}{c}30-40 \\
\text { torr }\end{array}$ & $>50 \mathrm{~m} / \mathrm{s}$ & $\sim 5 \mathrm{~cm}$ \\
\hline & & & & & $\begin{array}{l}\text { Spectra physics } \\
(5 \mathrm{~kW})\end{array}$ & 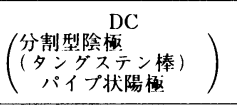 & $\begin{array}{c}30 \sim 45 \\
\text { torr }\end{array}$ & $50 \mathrm{~m} / \mathrm{s}$ & $\sim 3 \mathrm{~cm}$ \\
\hline & & & & & $\begin{array}{l}\text { 蔆電機 } \\
(9 \mathrm{k} \mathrm{WW})\end{array}$ & $\begin{array}{c}\text { DC+SD } \\
\text { SD : 無声放電 } \\
(100 \mathrm{kHz})\end{array}$ & $\begin{array}{c}100 \sim 300 \\
\text { torr }\end{array}$ & $30 \mathrm{~m} / \mathrm{s}$ & $\sim 7 \mathrm{~cm}$ \\
\hline & & & & & $\begin{array}{l}\mathrm{AVCO} \\
(15 \mathrm{~kW})\end{array}$ & 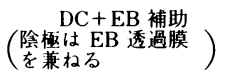 & 76 torr & $120 \mathrm{~m} / \mathrm{s}$ & $\sim 5 \mathrm{~cm}$ \\
\hline
\end{tabular}




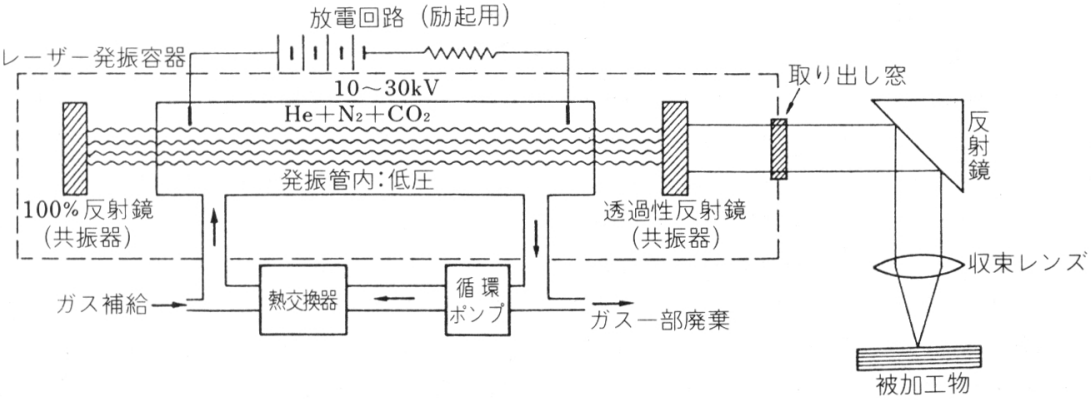

汹 1 軸流型 $\mathrm{CO}_{2}$ レーザー装置の構成闵 ${ }^{3)}$

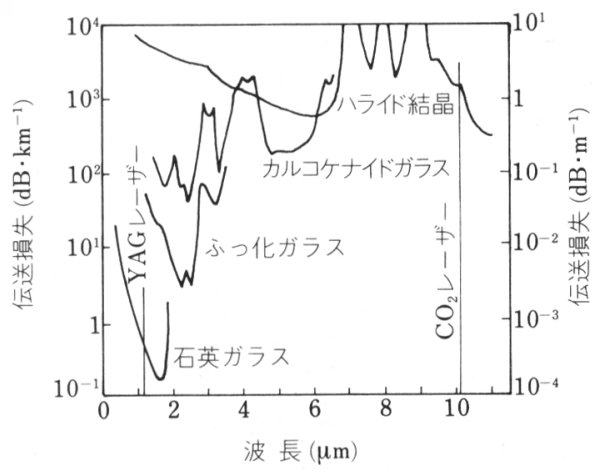

四 2 各種光ファイバーの伝送損失スペクトル4

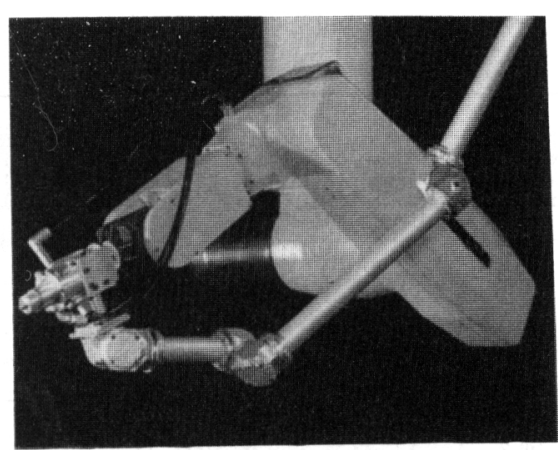

写真 1 フレキシブルビームガイド

高速軸流型においても $4 \sim 6 \mathrm{~kW}$ が最大出力である. 他 方 2 軸直交形及び 3 軸直交形は放電空間が大きく, かつ レーザー光軸に垂直にレーザー発振が起こるため，5 $25 \mathrm{~kW}$ の大出力を得ることができる.

$\mathrm{CO}_{2}$ レーザー加工装置は通常, 図 1 に示すように ${ }^{3)}$, 発振管あるいは放電チャンネル, 共振器, レーザーガス $\left(\mathrm{CO}_{2}, \mathrm{~N}_{2}, \mathrm{He}\right.$ の混合ガス) 循環・排気系, 加工光学系

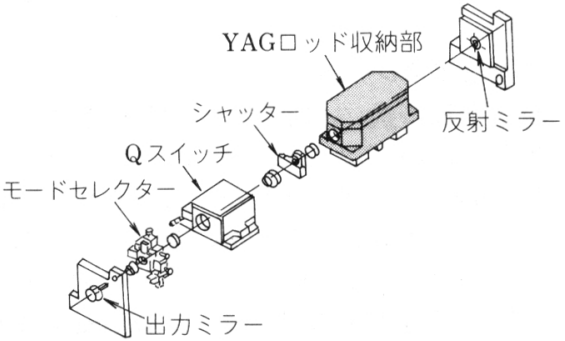

(a) YAGレーザー発振器

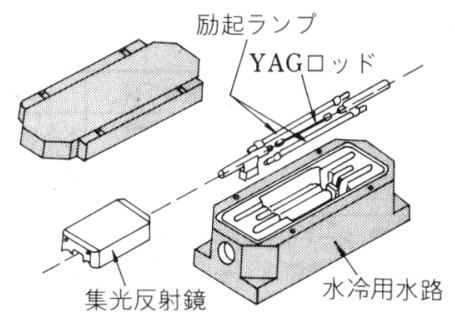

(b) YAGロッド収納部の詳細困

四 3 YAGレーザー発振器の主な構成要素5)

により構成される，各種レーザー加工には加工光学系も 重要で, 通常, $\mathrm{ZnSe}, \mathrm{KCl}$, あるいは $\mathrm{GaAs}$ などのレ ンズ，または銅，モリブデン，タングステンまたそれら に金めつきした金属ミラーが利用される。また、ビーム 伝送にはYAGレーザーでは石英ガラスの光ファイバー が用いられているが， $\mathrm{CO}_{2}$ レーザーは波長が長く $(10.6 \mu \mathrm{m})$, 光ファイバー伝送では図 $2^{4)}$ に示すように 伝送損失が大きく，研究開発段階である。 そこで，ビー ム伝送には写真 1 に示すようなフレキシブルなビームガ イドや通常のビームガイドが用いられている.

近年, 加工装置の改善が進められ，ビーム出力の安定 性の向上, パルス発振と連続発振の切換え, 数千時間連 続操業の信頼性, CNC 制御, 5 軸, 6 軸ロボットの出 現など著しく進歩し，オプトメカトロニクス，FA 時代 
の「ッール」として着実に成長している.

\section{$2 \cdot 2$ YACレーザー加工装置}

YAG（Yttrium Aluminium Garnet）レーザー加工装 置の基本構成の 1 例を図 $3^{5)}$ に示す. 直径 4 10 mm, 長さ 75〜150 mm の YAG ロッド及びそれを励起するフ ラッシュランプ（Xe，Kr ランプ）を集光反射鏡の中に 純水とともに配置している。この発振器を六つ連結し, $\mathrm{Kr}$ アークランプを用いた世界最大級の $1.4 \sim 1.8 \mathrm{~kW}$ YAG レーザー装置が, 国内の主要メーカーである東芝,

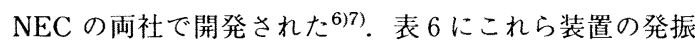
形態と加工の種類を示す ${ }^{8)}$. さまざまな発振形態が得ら れること，また，光ファイバーを用いて，罒 4 に示すよ うにビームを多分岐して利用できることも大きな特徵で ある。

\section{$2 \cdot 3$ その他加工用レーザー}

ここ 3〜5 年間に新しい加丁.用レーザーが開発され， 実用化の段階に入ろうとしている。 その一つがエキシ マー（Excimer）レーザーである．励起された二量体 （Excited Dimer）が励起状態から基底状態に落ちる時に 生ずるレーザーで，1970 年にソ連の D. G. BASOVらに より液体 Xe を電子ビームで励起して $172 \mathrm{~nm}$ の光を発

表 6 YAG レーザーの加工種別とさまざまな発振 形態8)

\begin{tabular}{|c|c|c|c|}
\hline 出力波形 & 加工の種類 & 競合手段 & 応用分野 (例) \\
\hline 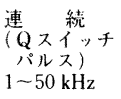 & $\begin{array}{l}\text { トリミング } \\
\text { マーキング }\end{array}$ & 機械的手段 & 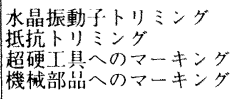 \\
\hline $\begin{array}{l}\text { 高速パルス } \\
(\sim 200 \mathrm{pps})\end{array}$ & $\begin{array}{l}\text { 連続(シーム)溶接 } \\
\text { 切 断 }\end{array}$ & \begin{tabular}{|l|} 
抵抗溶接 \\
ア一ク溶 \\
電子と尒溶接 \\
$3 う$ 付け \\
アーク切断
\end{tabular} & $\begin{array}{l}\text { リレー, ケース, 部品製 } \\
\text { 造 } \\
\text { 電算機部品 } \\
\text { 旺子管外册器 }\end{array}$ \\
\hline $\begin{array}{l}\text { 低速パルス } \\
(\sim 100 \mathrm{~J} / \mathrm{p})\end{array}$ & $\begin{array}{l}\text { 穴あけ } \\
\text { スポット溶接 }\end{array}$ & \begin{tabular}{|l|} 
譏械的手段 . \\
接着剂 \\
電子ビーム溶接 \\
抗溶接
\end{tabular} & 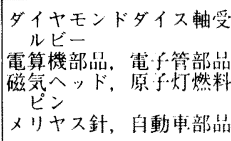 \\
\hline 続 & $\begin{array}{llll}\text { は } & \text { んう付 } & \text { け } \\
3 & j & \text { 付 } & \text { けt } \\
\text { 切 } & & & \text { 断 }\end{array}$ & $\begin{array}{l}\text { はんだごて } \\
\text { 機械的手段 }\end{array}$ & $\begin{array}{l}\text { フララット IC } \\
\text { 電算機部品 } \\
\text { 金禹溥板 }\end{array}$ \\
\hline
\end{tabular}

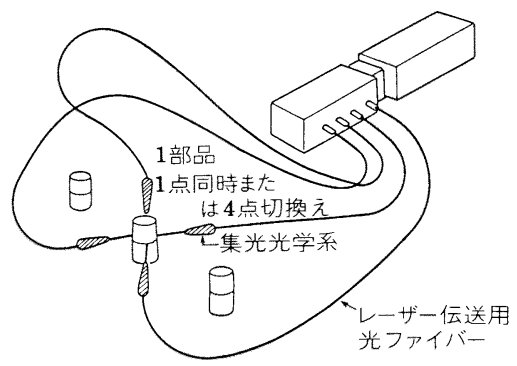

闵 44 分岐光ファイバー光学系
振したことに始まる。現在は放電励起方式（図 5 参 照) $)^{9)}$ が普及している。レーザーの種類と発振波長を表 7 に示す ${ }^{10)}$. 波長が紫外域にあるため，レーザーの光

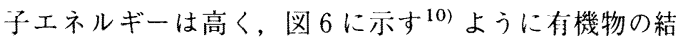
合エネルギーより高ければ，各種側鎖を切ることもでき る. R. SRINIVASAN ら (米国) はポリカーボネット樹脂を

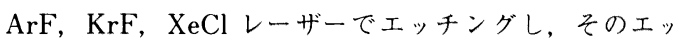
チング深さを測定している11). 最大出力は $100 \mathrm{~W}$ 程度 で，パルス幅は約 $10^{-8} \mathrm{~s}$, 最大絽这し成波数は䄪 200 $\mathrm{Hz}$ である．金属の合金化，七ラミックス膜の形成，ポ リマーの除去加工など光化学的または熱的加1として実 用化されている.

CO レーザー及びよう素レーザーの大出力化が我が国 で進んでいる。昭和 63 年秋には亡業開発研究所レー ザー研究センターと三菱重I. 業により， $3 \mathrm{~kW}$ 及び 5 $\mathrm{kW}$ の CO レーザー装置が共闹開発された. $3 \mathrm{~kW}$ の装 置を用いれば $40 \mathrm{~mm}$ 厚さのステンレス鋼柀を $50 \mathrm{~mm} / \mathrm{s}$

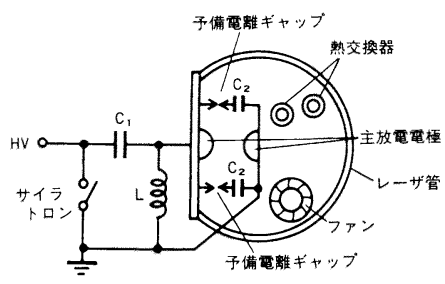

汹 5 エキシマーレーザー装置の構造9)

表 7 ガスの組合せと発振波長・光子エネル ギー10)

\begin{tabular}{c|c|c}
\hline & $\mathrm{F}$ & $\mathrm{Cl}$ \\
\hline $\mathrm{Xe}$ & $350 \mathrm{~nm}(81 \mathrm{kcal})$ & $308 \mathrm{~nm}(92 \mathrm{kcal})$ \\
$\mathrm{Kr}$ & $249 \mathrm{~nm}(114 \mathrm{kca})$ & $222 \mathrm{~nm}(128 \mathrm{kcal})$ \\
$\mathrm{Ar}$ & $193 \mathrm{~nm}(147 \mathrm{kca})$ & $175 \mathrm{~nm}(162 \mathrm{kcal})$ \\
$\mathrm{F}$ & $157 \mathrm{~nm}(180 \mathrm{kcal})$ & \\
\hline
\end{tabular}

)内は光子エネルギー, $E(=h \nu)$

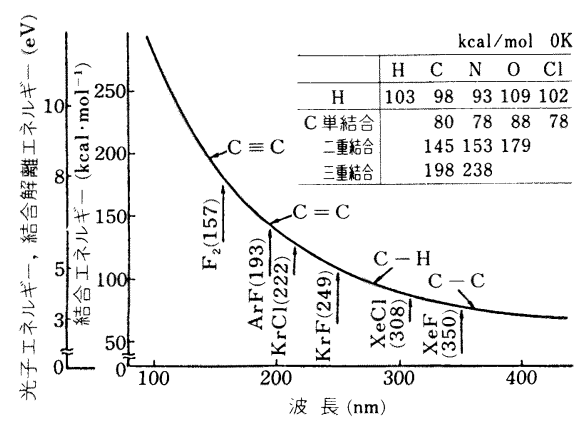

汹 6 レーザーの光子エネルギー及び分子の結令解 離エネルギーと波言の関係 ${ }^{10}$ 
表 $8 \mathrm{CO}$ レーザーと $\mathrm{CO}_{2}$ レーザーによる切断能 力の比較 (出力 起 : $3 \mathrm{~kW})^{12 \text { ) }}$

\begin{tabular}{c|cc}
\hline \multirow{2}{*}{\begin{tabular}{c} 
极 $(\mathrm{mm})$ \\
\cline { 2 - 3 }
\end{tabular}} & \multicolumn{2}{|c}{ 最人切断速度 $(\mathrm{mm} / \mathrm{s})$} \\
\hline 6 & $\mathrm{C}(\mathbf{L}$ レーザー & $\mathrm{CO}_{2}$ レーザー \\
10 & 4500 & 3500 \\
20 & 2600 & 1000 \\
40 & 400 & 切断不叮能 \\
\hline
\end{tabular}

の速度で切断できることが報告されている ${ }^{12)}($ 表 8 参 照)。また，不川舅播磨重工業は $3.1 \mathrm{~kW}$ で発振効率 $25.1 \%$ CO レーザー装置を開発するとともに, $100 \mathrm{~W}$ での光ファイバー伀送の川能性を確認している. 今後, - $120^{\circ} \mathrm{C}$ までの冷却系の改善, 低価格化, CO ガスの安 全性などの課題が解決され, 数 $\mathrm{kW}$ の大出力化が計ら れるとに業的に重要なレーザーとなろう。この他に, 波 長 $0.7 \sim 0.815 \mu \mathrm{m}$ のアレキサンドライトレーザー $\left(\mathrm{BeAl}_{2} \mathrm{O}_{4} に \mathrm{Cr}^{+3}\right.$ をドープした結晶体による) が波長 叮変レーザーとして, 開発されている，分あけ特性が非 常に優れており，穴あけをはじめ，アニーリング，化学 成忍にも利用されている。よう素レーザー（波長 : 1.32 $\mu \mathrm{m})$ もすでに $1 \mathrm{~kW}$ が前述のレーザー研究センターと 川崎重厂業とで開発され, 今後, 実用化に向けて, 研究 が進められることであろう。

\section{3. レーザー加工法の特徵}

物質はそれを構成する分子，原子，電子により，それ ぞれ周有の波言の光を吸収するので, レーザーの種類に よつても吸収率は異なる，通常，金属表面での光の吸収 率はレーザーの波昼に依你し次式で示される.

$$
\text { 吸収率 }=1-R=2 \sqrt{\frac{c}{\lambda \partial_{0}}}
$$

ここで， $R=$ 术射率， $c=$ 光の速度， $\lambda=$ レーザーの 波长, $\sigma_{0}=$ 物蜇の直流電気伝導度である. よつて $\mathrm{CO}_{2}$ レーザー（波長: $10.6 \mu \mathrm{m} ）$ よりも YAG レーザー（波 長 : $1.06 \mu \mathrm{m})$ の方が金属に吸収されやすい.しかし逆に, 七ラミックスは波長の产いレーザーの方が吸収されやす いことが確認されており, 加L対象物により適したレー ザーを選扒することが肝要となる.

さて，レーザーによる材料加丁は，他の加工法と比べ て一般的にどのような特徴があるか, 主な点を列挙する.

(1)高いパワー密度をもつ熱源である (図 7 参照).

( 2 ) 質量·慣性をもたない瞬間移動できる熱源である.

( 3 ) 非接触加1:である。非摩耗L具となる.

(4)微細で精密な熱加1ができる.

( 5 ) 大気中で, 磁気偏们やX 線の発生なく加工できる.

(6)ビームの吸収率は表面状態やビーム孔の形成など に著しく左右される。

( 7 ) 静かで, 騒音の少ない FA 化に適する加工法で

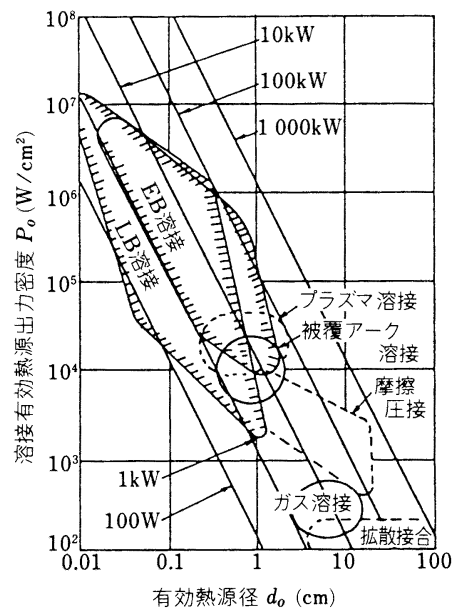

図 7 各種溶接法の溶接熱源出力密度

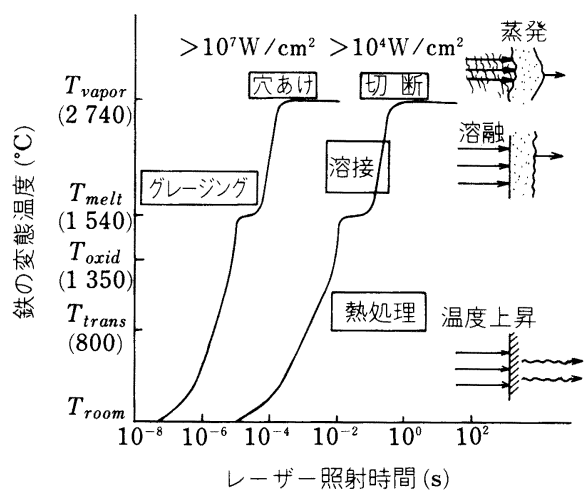

図 8 レーザー光を集光照射した材料の温度上昇と 照射時間の関係 ${ }^{13)}$

ある

(8)化学的にクリーンな熱源である.

これらの特徴を活かして, 従来不可能であつた材料加 工法が数多く開発されつつある.

\section{4. 各種レーザー加工法}

図 8 に示すように,材料にレーザー光が吸収されると， 材料が加熱·溶融・蒸発と変化を受ける。この現象を利用 して, 表面加工, 溶接, 除去加工などが行われる ${ }^{13)}$. 表 3 に示したレーザー加工法が開発され，表 9 に示すよ うに各分野で利用されている.この中では主な加工法に ついて述べる.

\section{$4 \cdot 1$ 溶接·接合加工 (Laser Welding)}

レーザーはパワー密度が $10^{4} \sim 10^{6} \mathrm{~W} / \mathrm{cm}^{2}$ のとき, 溶 融池にビーム孔を形成し，深溶込みの溶接ができる．図 
表 9 レーザー加I.の心用分野と加.I.例

\begin{tabular}{|c|c|c|c|}
\hline 産業分野 & 溶接 · 接合加丁: & 除 去 加 & 表 㮩 加 \\
\hline 電気機器産業 & $\begin{array}{l}\text { ・リチウム電池, リレーの溶接, 扇風機 } \\
\text { のろう付け } \\
\text { ·電気部品のシール溶接 } \\
\text { · TV 電子銃の点溶接 } \\
\text { ·制御盤パネルの点溶接 }\end{array}$ & $\begin{array}{l}\text { ·トランスパネルの切断 } \\
\text { ·プラスチック被覆銅線の切断 }\end{array}$ & ・冷咸庫用モーターシャフトの) PVD \\
\hline 電子·産業 & 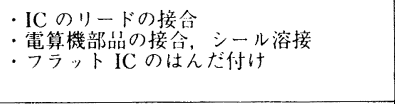 & $\begin{array}{l}\text { ·抵抗トリミング, ウェハーのスクライ } \\
\text { ビング } \\
\text { ・ICのマーキング } \\
\text { ・文スリリペアリンク }\end{array}$ & ・ICのアニーリング \\
\hline 白動車産業 & 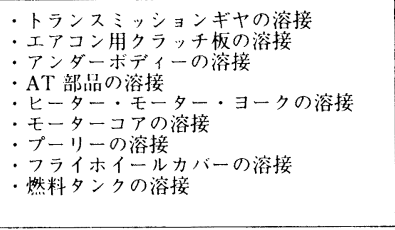 & 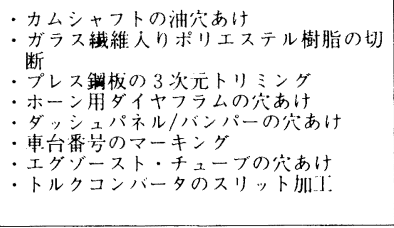 & 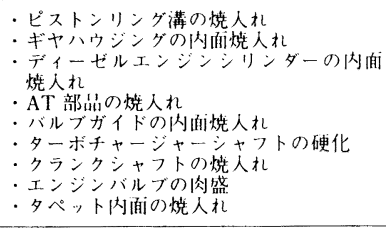 \\
\hline 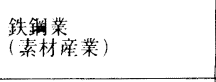 & $\begin{array}{l}\text { ·鋼板の板継ぎ } \\
\text { パイプの突きれせ念わ溶接 } \\
\text { ·チタン製及び鋼製かんの溶接 }\end{array}$ & 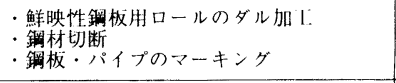 & ・けい尗鍼板の磁入緗分化 \\
\hline 産業機械 & $\begin{array}{l}\text { ·䤡柬, チェンソーの溶接 } \\
\text { 雷管のハーメチックシ }\end{array}$ & 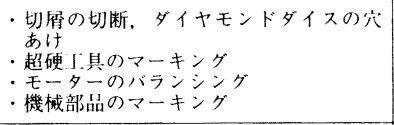 & 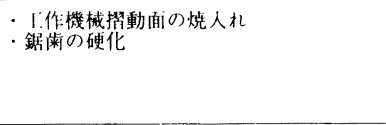 \\
\hline 造船·重機 & 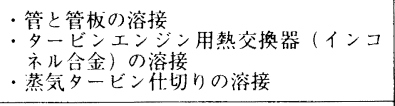 & ・タービンブレード六の枀あけ & 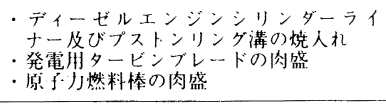 \\
\hline 精密機械産業 & & 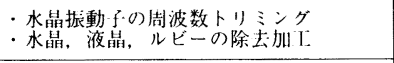 & \\
\hline 航空产業 & $\begin{array}{l}\text { ・八ニカム構造材, 薄肉チューブ, ベロー } \\
\text { ズの溶接 }\end{array}$ & 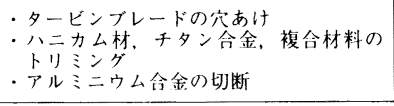 & $\begin{array}{l}\text { ·タービンブレードシュラウドの肉盛 } \\
\text { ·エンジンシリンダーの焼人れ }\end{array}$ \\
\hline 軽工業 & & 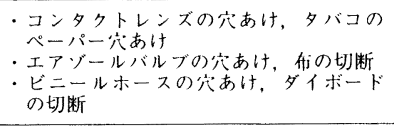 & \\
\hline その他 & $\begin{array}{l}\text { ·コーヒーパーカレーターの溶接 } \\
\text { · ボールペンカートリッジの溶 }\end{array}$ & $\begin{array}{l}\text { ・被覆線の皮むき } \\
\text { ・哺乳び蒠の允あけ }\end{array}$ & \\
\hline
\end{tabular}

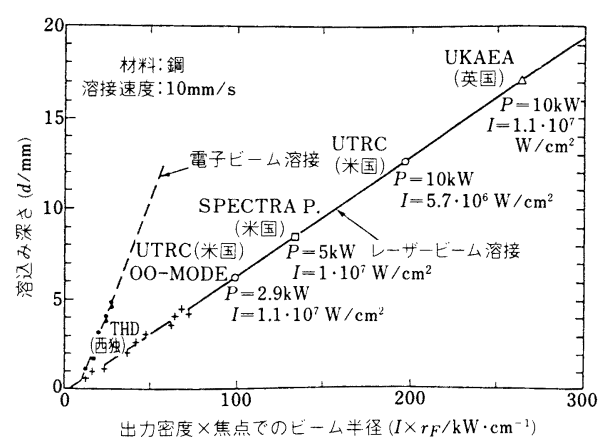

汹 9 溶込み深さと出力密度及びビーム半径の関 係 ${ }^{14)}$

9 は鋼をレーザー溶接した時の溶込み深さ $(d)$ に与え るレーザー出力密度 $(I)$ と焦点でのビーム半径 $\left(r_{F}\right)$ の 積の影響を示す ${ }^{14)}$. 㨁線関係にあるが, 電子ビーム溶接 の傾きよりもはるかに小さい。 なお，UKAEA-Culham

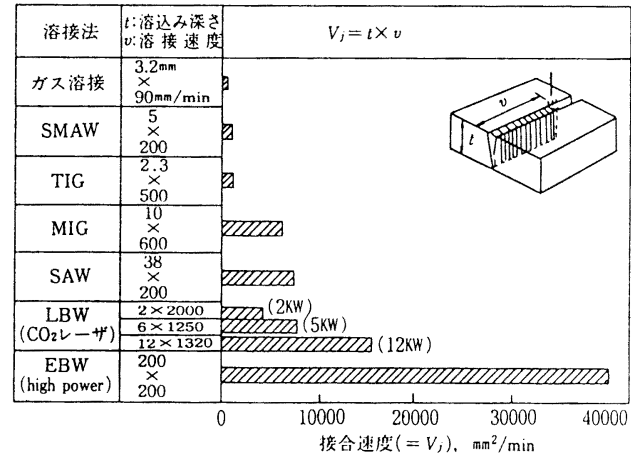

図 10 各種溶接法の接合速度の比較例（材料： 炭素鋼 $)^{16)}$
研究所の報告によれば $11.3 \mathrm{~kW} て ゙ ~ 5 \mathrm{~mm} / \mathrm{s}$ の速度の時 $25.4 \mathrm{~mm}$ の溶込みが得られている ${ }^{15)}$. 各種溶接法の接 合速度 $\left(V_{j}\right)$ を龱 10 に示す ${ }^{16)}$. $5 \mathrm{~kW}$ の出力で, 3 電 極サブマージアーク溶接の接合速度に㠩敵する。このこ 
とはレーザー溶接が生産性も十分高い溶接法であること を意味する，また，歪みが小さいこと，溶加材を必要と しないこと, 精密で高速な溶接法であるなどの利点があ り，実用化が進められている。

レーザー溶接が我が国の製鉄所の酸洗ライン入口で, コイルの板継ぎに 1981 年から利用されている ${ }^{17)}$.また, 最近自動車産業での適用が拡大している。例えばプー リーの溶接, トランスミッションギヤの溶接, パワース テアリング部品の溶接, ステーター・コアの溶接など月 产数万個の部品に適用され始めている. 西独ティッセン 製鉄会社では自動車アンダーボディの板継ぎにレーザー 溶接を適用している。米国 General Motor 社は約 300 台のレーザー装置を稼動させている，我が国においても 日本電装ではすでに 60 台のレーザー装置を導入してい る.その適用例を図 11 に示す ${ }^{18)}$. 従来のアーク溶接や プロジェクション溶接に代わつて, $1.2 \mathrm{~kW} の \mathrm{CO}_{2}$ レー ザーによりステーター・コアを $2.4 \mathrm{~m} / \mathrm{min}$ の速さで接合 している．電機産業においても小物や薄板からなる部品 を局部的に低歪みで精密に溶接するのに利用されてい る. 約 100 台のレーザー装置（主にYAG レーザー）を 配置した「レーザーストリート」をもつオランダのフィ リップス社ではカラー TV 電子銃部品の点溶接 ${ }^{19)}$ な゙, 社内部品の $10^{11}$ 点の抵抗溶接部をレーザーに置きかえ つつある. 加熱部を微小領域に限定でき, 溶接变形を極 小にできる利点を活かしている.

また, 各種機械部品の組立溶接にレーザーが利用され る. 米国 AVCO 社 Lycoming 部門では M1 型戦車搭載 用 AGT 1500 タービンエンジンの熱交換器のアニュ ラーコア部品の溶接にパルス発振型 $\mathrm{CO}_{2}$ レーザーを導

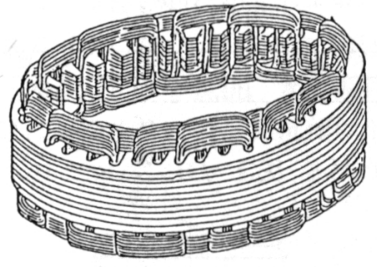

(a) ステーター・コア

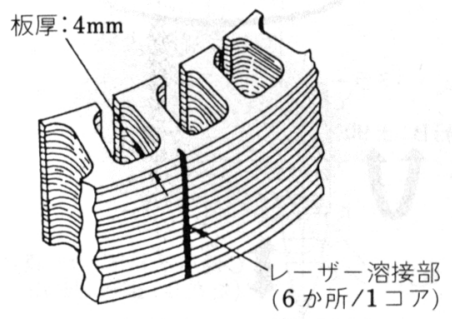

(b) けい素鋼板のレーザー溶接

汹 11 自動車ステーター・コアへのレーザー溶接の 適用 ${ }^{18)}$
入し， 2 交替制で日産 450 ペアを溶接組立てしている. また最近，米国ストッフェル溶接システム社は製缶用に 写真 2 に示すような 3 交替・週 7 日制に耐える高速軸流 型 $\mathrm{CO}_{2}$ レーザー装置を導入し，製缶に用いている ${ }^{20)}$. 自動車産業を中心に, 重稼動に耐える装置が要求されて いる。そこで, 米国, Control Laser 社では $6000 \mathrm{~h}(15$ か月）トラブルなしのシステムを提供している.

原子力産業においても原子炉制御棒 ${ }^{21)}$, 高速増殖炉 SPX2 の熱交換器の管板と管の溶接 ${ }^{22)}$, ジルカロイの 溶接 ${ }^{23)}$, ステンレス配管の溶接, 原子力発電プラント 用レーザーロボット ${ }^{24)}$ などが研究・開発されている.

他方，材料面からみると，炭素鋼，低合金高張力 鋼 $^{25)}$ ２8)，機械構造用鋼 ${ }^{29)}, \mathrm{Sn}$ めつき鋼板 ${ }^{30)}$, ステン レス鋼 ${ }^{31)}$-34), アルミニウム ${ }^{35)}$ 及びその合金 ${ }^{36) 37)}, \mathrm{Ni}$ 基超合金 ${ }^{38) 39)}$, 形状記憶合金 ${ }^{40)}$, 七ラミックス ${ }^{41) 42)}$, など多くの研究報告がある.

パイプ製造へのレーザー溶接の適用が検討されてお り, 電縫鋼管の厚肉化に対処する検討例がある ${ }^{43)}$. レー ザー溶接と他プロセスとの複合加工として注目される。 また,レーザーろう付けもすでに各種電気接点のろう付 け及び扇風機の FMS 生産ライン ${ }^{44)}$, フラットパック IC の搭載実装 ${ }^{45) 46)}$, 微細リードのセラミックス基板上 への接合などに実用化が進んでいる.これらは連続発振, あるいはパルス幅の広いYAG レーザーで行われてい る. 接合に必要なろう材の体積計算などの解析も進んで いる ${ }^{47)}$

\section{$4 \cdot 2$ 除去加工}

レーザービームを微小径に集光し，高エネルギー密度 を得ることにより，金属をはじめ各種材料の切断，穴あ けなどの材料除去加工が可能である，レーザー加工の応 用はこの分野が 70 ～80\% を占めている.

$4 \cdot 2 \cdot 1$ 切断・穴あけ (Laser Cutting and Drilling) レーザー切断・穴あけは他の加工法に比べて,

(1)高速で切断除去可能. 熱歪み及び熱影響が少ない.

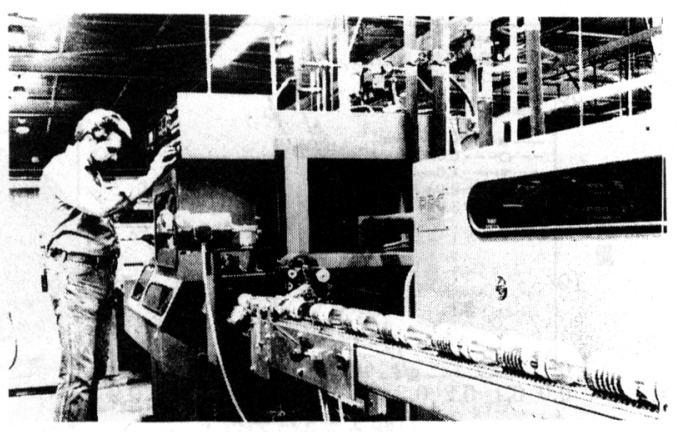

写真 2 米国 Stoffel 溶接システム社に導入された 製缶用高速軸流形 $\mathrm{CO}_{2}$ レーザー装置 ${ }^{20}$ 
(2)非接触のため, 脆性な薄板, 剛性の低い物も切断, 穴あけできる、摩耗する切断工具が不要.

(3)複雑な形状の高精度微細加工が可能.

(4)フレキシブルな三次元切断除去加工が可能.

( 5 )材料の歩留りが高い. カーフ幅が非常に狭い. などの特長があり，現在，紙，布，プラスチック，金属， セラミックス，コンクリートなど広範囲の材料の切断, 穴あけに利用されている、レーザー切断を大別すれば, 燃焼（酸化）反応を伴う燃焼切断と反応を伴わない非燃 焼切断とに分類できる．前者では切断ガスとして酸素ま たは空気を用い，後者ではアルゴンまたは窒素ガスを用 いる. 表 10 は各種材料の切断条件と切断ガスを示す ${ }^{48)}$. 金属材料の切断では薄板の高品質で，ドロスフリーの 切断が適正なパルス条件で可能となつている. ステンレ ス鋼，アルミニウム合金，チタン合金はドロスが付着し やすいため, ドロスフリーの高品質切断の研究が行われ ている ${ }^{49)}$-53). 図 12 はドロス付着量に及ばすパルス デューティの影響を示す ${ }^{54)}$. パルス切断では加工条件 には連続発振レーザー切断条件に加え，ピーク出力，周 波数,デューティ（=パルス時間/サイクル時間）など の条件があり，切断面粗さやドロス付着量をより適切に

表 10 各種材料のレーザー切断条件 $\left(\mathrm{CO}_{2}\right.$ レー ザー $)^{48)}$

\begin{tabular}{|c|c|c|c|c|}
\hline \multirow{2}{*}{ 材 } & \multirow{2}{*}{$\begin{array}{l}\text { 厚さ } \\
(\mathrm{mm})\end{array}$} & \multicolumn{2}{|c|}{ 切断速度 $(\mathrm{m} / \mathrm{mm})$} & \multirow{2}{*}{ 補助ガス } \\
\hline & & 出力 $400(\mathrm{~W})$ & 出力 $1000(W)$ & \\
\hline 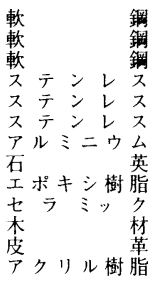 & $\begin{array}{c}1 \\
4 \\
6 \\
1 \\
3 \\
4 \\
1 \\
1 \\
0.5 \\
0.5 \\
10 \\
4 \\
8\end{array}$ & $\begin{array}{l}\sim 3 \sim \\
\sim 1 \sim \\
\sim 1.2 \sim \\
\sim 0.4 \sim \\
\sim 0.4 \sim \\
\sim 1.5 \sim \\
\sim 3 \sim \\
\sim 0.5 \sim \\
\sim 1.5 \sim \\
\sim 2.5 \sim \\
\sim 1 \sim\end{array}$ & $\begin{array}{c}\sim 4.5 \sim \\
\sim 1.5 \sim \\
\sim 1.0 \sim \\
\sim 2.5 \sim \\
\\
\sim 0.5 \sim \\
\sim 1.0 \sim \\
\sim 5 \sim \\
\sim 10 \sim \\
\sim 0.8 \sim \\
\sim 5 \sim \\
\sim 10 \sim \\
\sim 10 \sim\end{array}$ & $\begin{array}{c}\mathrm{O}_{2} \\
\mathrm{O}_{2} \\
\mathrm{O}_{2} \\
\mathrm{O}_{2} \\
\mathrm{O}_{2} \\
\mathrm{O}_{2} \\
\mathrm{O}_{2} \\
\mathrm{O}_{2} \\
\mathrm{~N}_{2} \text { たは Air } \\
\mathrm{Air} \text { または } \mathrm{O}_{2} \\
\mathrm{~N}_{2} \\
\mathrm{~N}_{2} \\
\mathrm{~N}_{2} \text { たは Air }\end{array}$ \\
\hline
\end{tabular}

（注）上記デー夕は，切断の最適値を示したものであり，集光レンズ， 補助ガスの厈力等により多少変化します。

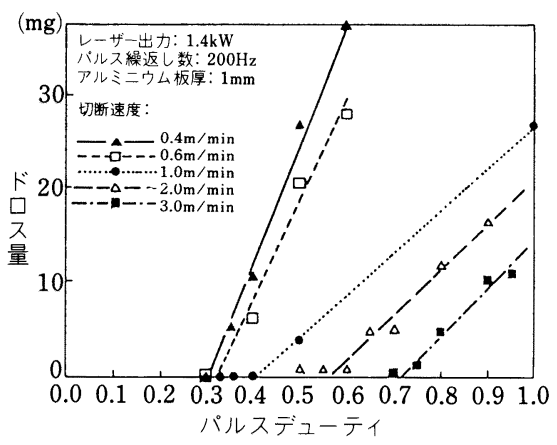

図 12 アルミニウム合金A5052 (1 mm 厚さ) のパ ルス炭酸ガスレーザー划断結果 ${ }^{54)}$
制御できる ${ }^{55)}$. また, 精密切断の部材先端部の切断で, ダレを防止する方法として，先端部で切断速度を変化さ せるとともに，ある臨界の速度以下では連続発振からパ ルス発振に切り換える制御法が開発されている ${ }^{56)}$. 他 切断法との比較を表 11 に示す ${ }^{57)}$.

非金属材料のレーザー切断例として，コンクリートの 切断 ${ }^{58)}$, 石英ガラスの切断 ${ }^{59)}$, 七ラミックスの切断 ${ }^{60)}$, ダイボードの切断 ${ }^{52)}$ などがある.

最近，自動車産業を中心に，プレス加工品やポリマー 部材の切断・穴あけに，三次元切断システムが稼動して いる。ロボットを用いたもの，ガントリー形 5 軸または 6 軸制御のもの，光ファイバーとレーザーロボットを結 合したシステムなどがある.三次元切断の場合, 加工へッ ドノズル先端と被加工物との距離を一定に保つ必要があ るが，5軸制御ではティーチング作業に多大な時間を要

表 11 各種熱切断法の比較 ${ }^{57)}$

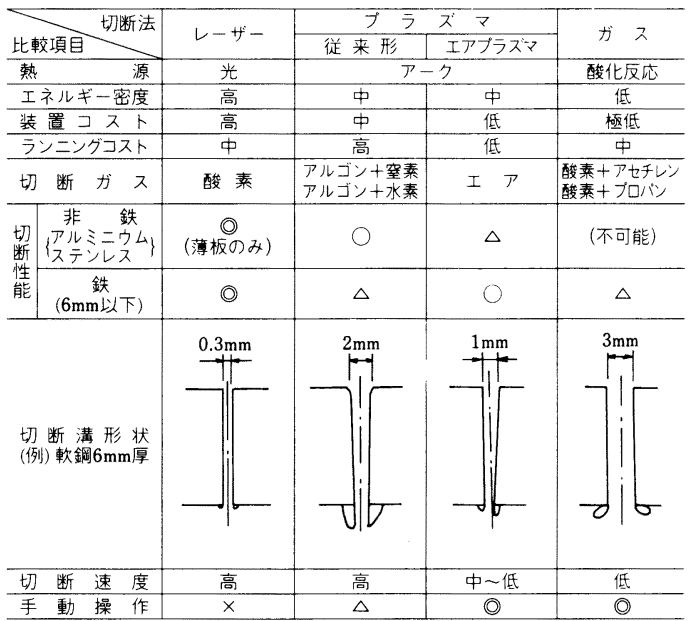

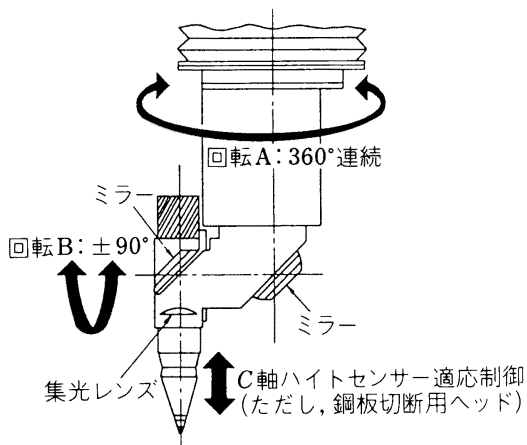

図 $13 X Y Z 3$ 軸テーブルに付けられる 2 軸回転ヘッド 及び適応制御される $C$ 軸 ${ }^{61)}$ 
する，そこでこの相対的位置関係を一定に保つため，図 13 のようにイタリアの PRIMA Industrie 社では 6 軸目 のC軸にハイトセンサーを付け，適応制御を適用してい $3^{61)}$. 原子力関係では核燃料集合体のレーザー切断（解 体） システムの開発 ${ }^{62)}$ 及び, 解体切断として, 新しい $\mathrm{CO}$ レーザーと KrF レーザーを同時に用いたステンレ 又鋼 (6 mm 厚) の切断例 ${ }^{63)} も$ ある。また, $\mathrm{CAD} / \mathrm{CAM}$ を導入したシステムやパンチプレスとレーザー切断を結 合した例, FMS の中に数台のレーザーを導入した例な ど，メカトロニクスとレーザー加工技術が融合したオプ トメカトロニクスが開発され, 今後, 情報化社会の要求 である多品種小量生産に, ますます利用されようとして いる.

穴あけ技術では Nimonic 合金製ガスタービン部品の 穴あけ，ダイヤモンド等硬質材の穴あけ，コンタタトレ ンズの穴あけ, 紙巻たばこのフィルター部のチップペー パーの穴あけなど行われている。最近注目されるエキシ マーレーザーによるポリマーの穴あけの例を写真 3 に示 す64). YAG レーザーや $\mathrm{CO}_{2}$ レーザーによる熱加工で はポリーミドが変質するが，エキシマーレーザーでは変 質なしに光分解により穴あけが可能である。また，アレ キサンドライトレーザー（中心波長 $755 \mathrm{~nm}$ ) は YAG レーザー（波長 $1063 \mathrm{~nm}$ ) やルビーレーザーより発振 しきい值が低く，エネルギー蓄積形であるので高ピーク 出力を必要とする金属の穴あけに適しており，銅 $(5 \mathrm{~mm}$ 厚まで), 黄銅 (7 mm 厚まで), 純アルミニウム $(8 \mathrm{~mm}$ 厚まで) の穴あけが可能である ${ }^{65)}$

$4 \cdot 2 \cdot 2$ 微細加工 (Laser micro-processing)

半導体産業における微細加工（トリミング，スクライ ビング，マーキング，リペアリング，バランシング，マ イクロソルダリングなど）に現在レーザーが適用されて いる ${ }^{66)}$. 微細除去加工として, HIC (混成集積回路), 抵抗ネットワーク, チップ抵抗, 水晶振動子などの電気 抵抗を設計値に調整するため, 抵抗体の 1 部をレーザー で除去するトリミング, IC, LSI などのシリコン基板
及び HIC などのアルミナセラミックス基板を素子製造 後分離するためにレーザーで断続的な穴あけを行い切込 みを入れるスクライビング，ホトマスク製造時に発生す る残留欠陥を効率良く修正するレーザーリペアリング, およびマイクロモーターなど回転体のダイナミックバラ ンシングがあり，主に，YAGレーザーが用いられてい る. LSI のレジストレスのパターン転写エッチングに は $\mathrm{ArF}$ エキシマーレーザーが検討されている67).

$4 \cdot 2 \cdot 3$ マーキング (Laser marking)

$\mathrm{CW}$ 及び高速パルス YAG レーザーによるスキャンニ ング方式マーキングと TEA (Transverse Excited Atmospheric) $\mathrm{CO}_{2}$ レーザー及びパルス YAG レーザー によるマスク方式マーキングが近年実用化され，急激に その適用範囲が拡大している，前者は主に金属へのマー キング，後者は主に非金属のマーキングに利用されてい る. 米国では社会的要請, 例えば化粧品の東南アジア地 域での偽造防止, 食料品の保管管理, 製品の追跡調査, などのため，マーキングの必要性が増大している。また 西独でもビール製造直後のナンバーリングの義務のため レーザー・マーカーで午やビンのラベルにマーキングさ れている。また，多品種少量生産にバーコードを活用す るニーズが予測されるが，既に国内で鋼板の管理にレー ザーマーキングを検討している ${ }^{68)}$. 従来のインク方式 では線径が $100 \mu \mathrm{m}$ であつたものが，レーザーにより 20 30 $\mu \mathrm{m}$ と細く, 微細で, 非接触でしかも高速にマー キングできる. 図 14 にマーキング方式を ${ }^{69)}$, 図 15 に 1 パルスでマーキングできる面積の比較を示す65)。 レキサンドライトレーザーも今後利用されよう。

\section{$4 \cdot 3$ 表面加工 (Laser surface processing $=$ LSP)}

既に表 3 に示したように，レーザー表面加工は大別し て加熱, 溶融, 蒸発及び化学反応プロセスに分けられる. 近年,この分野の研究開発は米国，日本を中心に各国で 活発に行われている. なぜなら, 従来の熱源に比べて, 化学的には完全にクリーンであり，表面処理には理想的 な特性をもち，騒音もなく自動化に適しているからであ

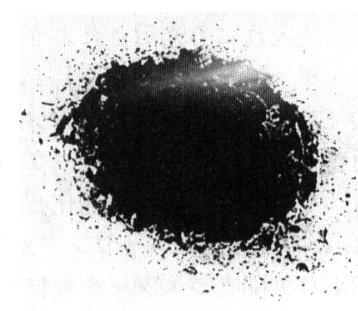

(a) YAGLーザ

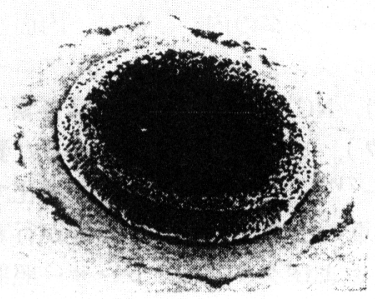

(b) 炭酸力”ス レーサ”

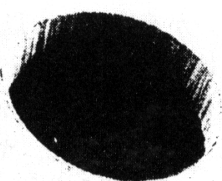

(c) Iキシ子 レー\#”

写真 3 板厚 $75 \mathrm{~mm}$ のポリーミドの各種レーザーによる穴あけ状況（穴径 300 ミクロン $)^{64)}$ 


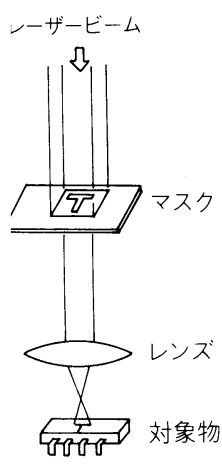

(a) マスク方式

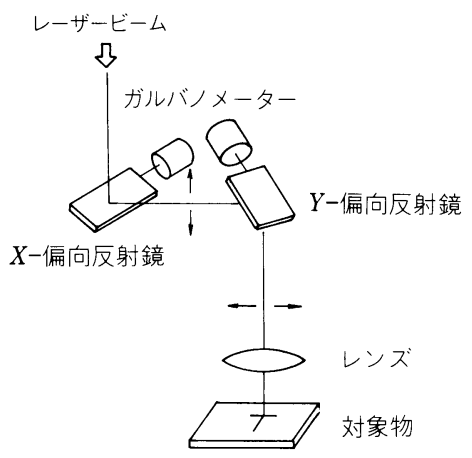

(b) スキャンニング方式

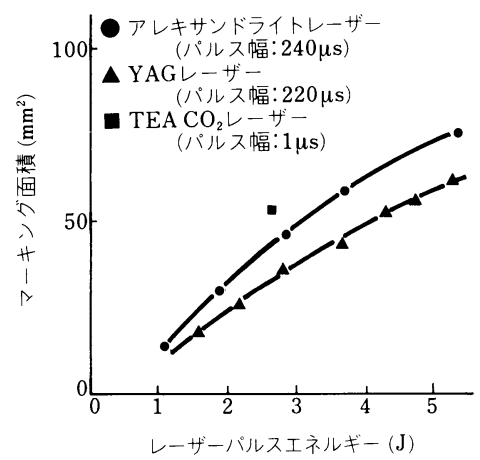

网 15 異なるレーザーによるマーキングにおける 1 パルスでマーキングできる最大面積の比較（同一 エネルギー $)^{65)}$

図 14 レーザーマーキングの方式 ${ }^{69)}$

表 12 レーザー焼入れの部品への適用例 73

\begin{tabular}{|c|c|c|c|c|c|c|c|}
\hline 品 & 料 & $\begin{array}{c}\text { レーザーパワー } \\
(\mathrm{kW})\end{array}$ & $\begin{array}{c}\text { ビーム形状 } \\
(\mathrm{mm})\end{array}$ & $\begin{array}{l}\text { 移動速度 } \\
(\mathrm{mm} / \mathrm{s})\end{array}$ & 吸 収 剂 & $\begin{array}{c}\text { 硬化深さ } \\
(\mu \mathrm{m})\end{array}$ & $\begin{array}{l}\text { 硬 度 } \\
\left(H_{R} C\right)\end{array}$ \\
\hline スペーサ & マリアプル鋳鉄 & 15 & $12.7 \times 12.7$ 角 & - & 黒 & 305 & 58 \\
\hline ピストンリング淮 & ねずみ鋳鉄 & 3 & $12.7 \times 12.7$ 角 & - & 第 & 381 & - \\
\hline バルブシート & 鋳鉄 & 6 & (2) & - & 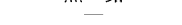 & 762 & - \\
\hline カムシャフト & ダクタイル鋳鉄 & 10 & -- & - & & 1016 & 60 \\
\hline シャフト & AISI $4140 \mathrm{H}$ 銅 & 10 & アニュラービーム & 12.7 & $\ldots$ & 381 & 55 \\
\hline スプラインギヤ & - & 10 & 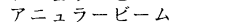 & 12.7 & - & 381 & \\
\hline クラシクシャフトのフィレット & ダクタイル鋳鉄 & 13 & フォーカスビーム & $4 \mathrm{~s} / \mathrm{rev}$ & $r=-\bar{n}$ & 1015 & $55-62$ \\
\hline $\begin{array}{l}\text { シリンダー }(\phi 25.4 \mathrm{~mm}) \\
\text { カムシャフト }\end{array}$ & $\begin{array}{l}\text { AISI } 4140 \mathrm{H} \text { 鍊 } \\
\text { ダクタイル鋳鉄 }\end{array}$ & $\begin{array}{c}3.5-7.5 \\
9\end{array}$ & $\begin{array}{l}\text { アニュラービーム } \\
23 \times 25 \text { 矩形 (オシレー }\end{array}$ & $\begin{array}{c}1300 \mathrm{rev} / \mathrm{min} \\
12.7\end{array}$ & $\begin{array}{l}\text { ブラックペイント } \\
\text { クん酸マンガン }\end{array}$ & $\begin{array}{c}1523-2032 \\
560\end{array}$ & $\begin{array}{c}45 \\
50-55\end{array}$ \\
\hline ギヤの歯 & AISI 1045 鋼 & 8.8 & $12.7 \times 12.7$ 角 (ビーム & $\begin{array}{l}8.5 \\
8.5\end{array}$ & ブラックペイント & $1165-1132$ & $59-60$ \\
\hline シャフト $(\phi 9.5 \mathrm{~mm})$ & AISI 1060 鋼 & 0.5 & 処理量 $97 \mathrm{~mm}^{2} / \mathrm{s}$ & & - & 508 & $62-64$ \\
\hline スプライシギヤ & AISI 1050 龬 & 0.5 & $54 \mathrm{~mm}^{2} / \mathrm{s}$ & & & 381 & 60 \\
\hline カッティングブレード & AISI 1050 铜 & 0.5 & $43 \mathrm{~mm}^{2} / \mathrm{s}$ & & - & 635 & $60-64$ \\
\hline $\begin{array}{l}\text { シリンダーライナー } \\
\text { ベアリング部品 }\end{array}$ & ねずみ鋳鉄 & 1.5 & $108 \mathrm{~mm}^{2} / \mathrm{s}$ & & & & $55-60$ \\
\hline $\begin{array}{l}\text { ベアリング部品 } \\
\text { パワーステアリ゙ }\end{array}$ & ねずみ鋳鉄 & 1.5 & リングモート & 42 & り人酸マンガン & $\begin{array}{c}457 \\
254-356\end{array}$ & - \\
\hline ギヤハウジング & 可锻鋳鉄 & & $\left(\phi 1.8 \mathrm{~mm} . \mathrm{TEM}_{\mathrm{Ol}}\right)$ & & 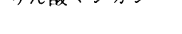 & & \\
\hline クラフトペーパー用ロール(27501b) & & 1.2 & & 一 & & 1016 & $60-63$ \\
\hline 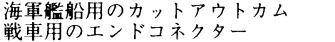 & $\begin{array}{l}\text { AISI } 4340 \text { 鋼 } \\
\text { AISI } 4140 \text { 鋼 }\end{array}$ & 1.2 & 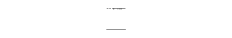 & - & $\begin{array}{l}\text { カーポン } \\
\text { Krylon } 1602\end{array}$ & $\begin{array}{c}381-432 \\
305\end{array}$ & 55 \\
\hline タイプライタ用インターボーザー & & 1.2 & - & & $\begin{array}{l}コ \text { コダルグラ } \\
\text { ファイト }\end{array}$ & 1016 & \\
\hline シリンダーライナー & 鋳鉄 & 5 & $\phi 19 \mathrm{~mm} ヒ ゙ ー ム$ & - & ブラックコーティ & 635 & - \\
\hline バルブガイド & ねずみ鋳鉄 & 0.4 & $\phi 19 \mathrm{~mm} ヒ ゙ ー ム$ & 4.2 & & & \\
\hline
\end{tabular}

る. 主な表面加工法についてトピックス的に述べる. $4 \cdot 3 \cdot 1$ 加熱プロセス

( a )変態焼入れ (Laser transformation hardening) 1974 年に米国 GM 社で自動車のギヤハウジングの内 面焼入れにレーザーが適用されて以来，エンジンシリン ダライナーの内面焼入れ ( $\mathrm{GM}$, 三菱重工), $\mathrm{NC}$ 施盤用 ベッドの摺動面の焼入れ（富士ファナック），ピストン リング溝の焼入れ (川崎重工 ${ }^{70)}$, ヤンマー ${ }^{71)}$ ), クラン クシャフトコーナー部の焼入れ ${ }^{72)}$, 自動車のセラミッ クス製ターボチャージャロータのシャフトおよびクラッ チドラムの焼入れ $(\text { 日産 })^{72)}$ など多くの適用例を見るに 至つた. 表 12 にレーザー焼入れの適用状況を示す ${ }^{73}$. 炭素鋼, $\mathrm{C}-\mathrm{Cr}$ 鋼の焼入れ ${ }^{74)}$, 過共析鋼の焼入れ ${ }^{75)}$, 鋳

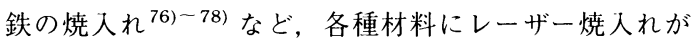

適用されたとの報告がある.

レーザー出力のアップとともに，単位時間当たりの焼 人れ面積が増してきたが，今後は狭あい部分，複雑形状 部品，内面などの焼入れにも適用されよう.

\section{( b )アニーリング (Laser annealing)}

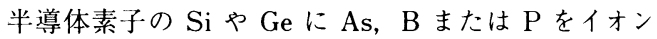
注入すると表面層に非晶質層や転位ループが生じ電気的 特性が劣化する，そこでこれらを結晶化し，転位をなく す処理が行われ,この処理をアニーリングと呼んでいる. レーザー照射により欠陷クラスターや転位ループを隇少 できる．また，超電導材 $\mathrm{Nb}_{3}(\mathrm{Al}, \mathrm{Ge})$ でテープを作 成するのに，焼結されたこの材料に $\mathrm{CO}_{2}$ レーザー照射 することにより，遷移温度 $\left(T_{\mathrm{c}}\right)$ を $18.6 \mathrm{~K}\left(\mathrm{Nb}_{3} \mathrm{Al}\right)$ 及 び $20.1 \mathrm{~K}\left(\mathrm{Nb}_{3}(\mathrm{Al}, \mathrm{Ge})\right)$ とすることに成功してい 
$ろ^{79)}$.

(c)ステンレス鋼の表面溶体化処理（Solution treatment)

ステンレス鋼溶接継手のウェルド・ディケイ（Weld decay）は粒界にクロム荘化物が析出するため生ずるが, この部分をレーザーにより $1100 \sim 1300^{\circ} \mathrm{C}$ に短時間加 熱することにより, 炭化物が分解・再固溶し, 耐食性劣 化を防止できることが報告された ${ }^{80) 81)}$ ，表面層を急熱・ 急冷できるため, 隣接部の炭化物析出を抑え, 表面のみ 溶体化できる.

\section{$4 \cdot 3 \cdot 2$ 溶融プロセス}

(a)合金化 (Laser alloying)

金属表面に新しい今金層，化合物層を作る力法で，多 くの研究があるが，実用化された例は少ない，合金層と しては急熱・急冷プロセスのため, 過飽和な, 非平衡相 を均一微細組織として得ることもできる，炭素鋼表面に グラファイトを塗布し，レーザー表面溶融すると溶融部 の炭素量は汹 16 のように増し, その硬さも増大する ${ }^{82)}$. 炭化, 空化 ${ }^{83)}$, 鋼管内面のチタン被膜生成 ${ }^{84)}$, タング ステン合金化 ${ }^{85)}$, 高 $\mathrm{Cr}$ 化, $\mathrm{TiAl}_{6} \mathrm{~V}_{4}$ 合金への TiN 被 膜生成 ${ }^{86)}, \mathrm{Ni}-\mathrm{Cr}$ 合金へのク口ム炭化物被膜生成 ${ }^{87)}$, $\mathrm{Al}-\mathrm{Si}$ 鋳物表面の鉄命金化による硬化処理 ${ }^{88)}$ など興味 ある報告がある。また，レーザー合金化の研究例を 101 件整理した報告もある ${ }^{89}$.

( b ) 肉盛 (Laser cladding)

レーザー肉盛は婮部的な肉盛に実用化されている。 ロールスロイス社では夕ービンブレードシュラウドの レーザー肉盛を実用化している。 トヨ夕自動車はエンジ ンバルブにステライト＃32をレーザー肉盛する加工法 を実生産ラインに導人した。威17 は木材切削刃物の刃 先をレーザーにより軟鋼に高速度鋼粉木と $40 \%$ の VC

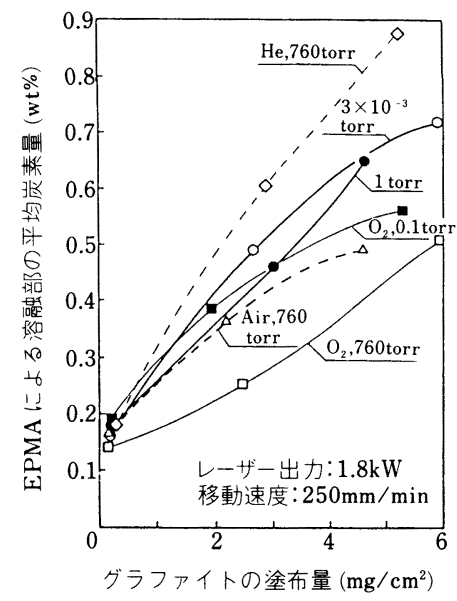

网 16 グラファイト塗布量と溶融部の炭素含有量 の関係 ${ }^{82)}$
粉末を肉盛して作り，それを摩耗試験した結果を示す. 40\%の VCを添加し，大きな炭化物を均一に分布させ ることにより，高速度鋼に比べて，約 10 倍の寿命を得 た ${ }^{90)}$. 最近レーザー肉盛作業標準も作られた ${ }^{91)}$.

(c)表面溶融 (Laser surface melting)

表面溶融には, 従来のアーク溶接部と同程度の凝固速 度の通常凝固プロセス, 組織の微細化, 準安定相の生成, 均質化が十分期待できる急速凝固プロセス及び非晶質化 まで可能なほど速い超急速凝固プロセス（Laser glazing）がある.

ステンレス鋼の表面溶融では, 得られる顕微鏡組織が 従来のシェフラー状態四で推定されるものと著しく異な $\eta^{92)}$ ，耐食性 ${ }^{93)}$ および酎酸化性が向上すること积 も見 出されている。また，溶射層の気孔率の低減と均質化を 図るレーザーコンソリデーション95)，自動車用鮮映性 鋼板を生産する压延ローラーのダル加工 ${ }^{-96)}$ ，および高 張力鋼溶接継手の止端部再溶融による疲れ強さの改善 (汹 18 参照) ${ }^{97)}$ など, 最近興味深い開発がなされてい

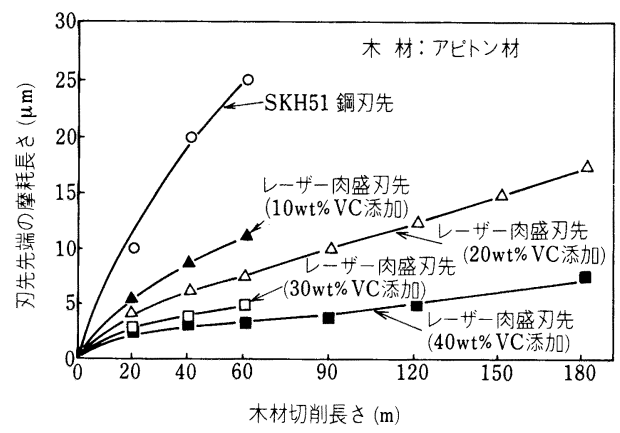

図 $17 \mathrm{VC}$ 混合金属粉末のレーザー肉盛刃先の摩 耗試験結果 ${ }^{90)}$

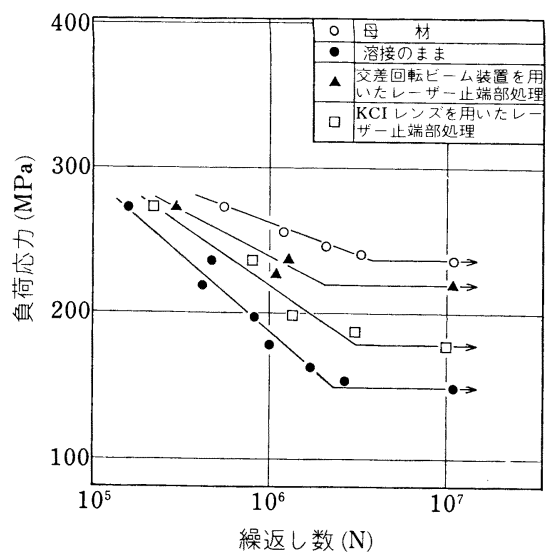

四 18 SM50 鋼溶接継手のレーザー止端部処理に よる疲れ強さの改善 ${ }^{97)}$ 
る. 鋳鉄のチル処理により, 表面改質し, 酎摩耗性を向 上できる ${ }^{98)}$.レーザーによる金属の加熱速度打よび冷 却速度は非常に早く，それぞれ数万 ${ }^{\circ} \mathrm{C} / \mathrm{s}$, 数千一数万 ${ }^{\circ} \mathrm{C} / \mathrm{s}$ の值を得ることもでき，金属表面をアモルファス 化することも可能である ${ }^{99)}$. 広い表面をアモルファス 化できる。

\section{$4 \cdot 3 \cdot 3$ 蒸発プロセス}

(a) レーザー物理蒸着 (Laser physical vapour deposition)

レーザーPVD 法を用いて，レーザー光吸収体（Mo 基板）表面に $\mathrm{BN}$ 薄膜を蒸着した例，アルミニウム基 板に $\mathrm{Al}_{2} \mathrm{O}_{3}$ 膜を蒸着した例 ${ }^{100)}$ が報告されている。冷 蔵庫の压縮機用モーターシャフト (アルミニウム合金) へのセラミックス膜蒸着が実用化されている ${ }^{100)}$.

( b ) その他蒸発プロセス

$3 \%$ けい素電磁鋼板の表面に張力皮膜をつけ，パルス レーザーでこの皮膜を蒸発させるとき生ずる衝撃波で鋼 板表面に微小歪みを誘起し，磁区を細分化し，鉄損を約 10\% 低下させるレーザー加工がわが国製鉄所で実用化 されている101)。また，アルミニウム合金や SUS316 鋼 の表面に水または石英を塗布し，レーザーでこの皮膜を 蒸発させ， $5 \mathrm{GPa}$ 以上の压力を材料に与え硬化する衝 撃硬化 (Laser impact hardening) も研究されている. $4 \cdot 3 \cdot 4$ 化学反忍プロセス

(a) レーザー化学蒸着 (Laser chemical vapour deposition)

最近レーザーCVD やレーザーエッチングなどレー ザー光化学度応を利用したプロセスが注目されている.

低温で薄膜形成が叮能で, 膜成長速度, 膜厚をレーザー 出力で制御できる．Ar イオンレーザーによるシリカガ ラス基板への鉄の蒸着 $\left(\mathrm{Fe}(\mathrm{CO})_{5} \rightarrow \mathrm{Fe}\right)^{102)}, \mathrm{ArF} レ ー$ ザーによる $\mathrm{Si}$ または $\mathrm{SiO}_{2}$ 基板への $\mathrm{TiSi}_{2}$ の蒸着 $\left(\mathrm{SiH}_{4}+\mathrm{TiCl}_{4} \rightarrow \mathrm{TiSi}_{2}\right)^{103)}, \mathrm{ArF}$ レーザーによる $\mathrm{SiO}_{2}$ 基板へのタングステンの蒸着 $\left(\mathrm{WF}_{6}+\mathrm{H}_{2} \rightarrow \mathrm{W}\right)^{104)}, \mathrm{Si}$ 基板上へのダイヤモンド薄膜の成長，及びその他金属膜 の蒸着などのレーザー CVD がある105)。レーザー励起 エッチング (Laser assisted etching) は光エネルギーで 成心性ガスや液を材料と度応させエッチングする方法 で，高能率である． $\mathrm{Si}, \mathrm{GaAs}$ などの基板に対する損傷 が少ない，新日本製鉄では最近，硝酸系溶液中につけた ステンレス鋼にパルスレーザーを照射し，酸化被膜の厚 みを制御し，青，金，緑など 7 色を同時に着色できる加 厂法を開発した，CAD との組合せで色模様を出すこと ができ，経済性が極めて高い．

その他, レーザーリソグラフィによる高分子膜の形成, めつき加速处理（めつき反忘速度の向上）などが研究開 発されている。

\section{$1 \cdot 4$ その他}

以上述ベたレーザー加I法以外に, 新しい加エ法が開
表 13 各種レーザー装置の需要現状 (1986 年) と 予測 $(1991 \text { 年 })^{113)}$

\begin{tabular}{|c|c|c|c|c|}
\hline 分類 & 光 製 品 & 単位. & 1986 年度 & 1991 年度 \\
\hline 光 & 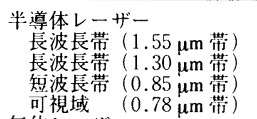 & $\begin{array}{l}\text { 個 } \\
\text { 個 } \\
\text { 倜 }\end{array}$ & $\begin{array}{r}1300 \\
24000 \\
600000 \\
8100000\end{array}$ & $\begin{array}{r}4500 \\
120000 \\
2900000 \\
97000000\end{array}$ \\
\hline 部 & 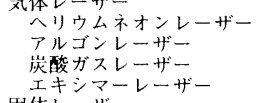 & $\begin{array}{l}\text { 台 } \\
\text { 枲 } \\
\text { 点 } \\
\text { ti }\end{array}$ & $\begin{array}{r}67000 \\
1100 \\
700 \\
50\end{array}$ & $\begin{array}{r}86000 \\
2600 \\
2500 \\
680\end{array}$ \\
\hline & $\begin{array}{l}\text { ル } \\
\text { ガラスーレーザー } \\
\text { YAG レーザー }\end{array}$ & 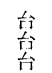 & $\begin{array}{r}8 \\
2 \\
750\end{array}$ & $\begin{array}{r}8 \\
2 \\
2900\end{array}$ \\
\hline \multirow{8}{*}{$\begin{array}{l}\text { 光 } \\
\text { 機 } \\
\text { 器 } \\
\text { 装 } \\
\text { 置. }\end{array}$} & \multirow{8}{*}{ 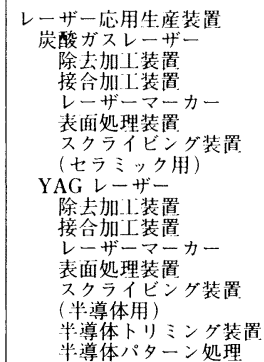 } & & & \\
\hline & & 台 & 240 & 720 \\
\hline & & ti & 50 & 610 \\
\hline & & $\begin{array}{l}\text { 育 } \\
\text { 台 }\end{array}$ & $\begin{array}{l}15 \\
45\end{array}$ & $\begin{array}{l}370 \\
150\end{array}$ \\
\hline & & 台 & 30 & 100 \\
\hline & & 台 & $\begin{array}{l}200 \\
110\end{array}$ & $\begin{array}{r}840 \\
1100\end{array}$ \\
\hline & & 育 & $\begin{array}{r}10 \\
5\end{array}$ & $\begin{array}{l}45 \\
30\end{array}$ \\
\hline & & 台 & 330 & 1000 \\
\hline
\end{tabular}

発され，実用化が検討されている。それを次にあげる.

( i ) 新材料の製造法: 微粒子の生成 ${ }^{106)}$, FRM の製 造 ${ }^{107)}$ など

(ii)レーザー切削成形法 ${ }^{108}$

(iii)金属板の曲げ加-1 ${ }^{-109) 110)}$

(iv)ガラスや岩石の割断扩よび破砕

\section{5. あとがき}

レーザー加上技術は米国，日本，西独を中心として， 工業先進国で急速に実用化が進んでいる ${ }^{111112)}$. 我が国 も 80 年代に入り, 電気・電子㸚業, 自動車産業, 鉄鋼 業を中心に実用化が進み，表 13 に示すように113), 1986 年には $\mathrm{CO}_{2}$ 及放び YAG レーザー介わせて 1450 台 の需要実績となり，1991 年には 5000 余台が予測され ている. 今後, (1)新加工用レーザーの開発, (2)加1.光学: 系及びビーム伝送技術の発展, (3)新しいレーザー加亡法 の開発, (4)FA・FMS への導人システムの開発などによ り，ますます，レーザー加技術が近代l場で不叮欠の 「熱加T.下具」として利用されるであろう。

\section{文献}

1 ) 沓名宗春: 溶接技術, 35 (1987) 1, p. 60

2 ) 益本 功, 沓名宗春: 機械の研究, 36 (1984), p. 459

3 ) 益本 功, 寺井精英: 溶接技術, 29 (1981) 9, p. 17

4 ）坂口茂樹, 高橋志郎: 第 22 回東北大通研シンポジウム論 文集 (1986), p. 1

5 ）小松 嚴, 末永直行: 溶接技術, 35 (1987) 8, p. 62

6 ) 木村博一: 溶接技術, 36 (1988) 8, p. 66

7 ) K. OKIno and H. Takenaka: KIEE Annual Conf. Seoul, Korea (1988 年 11 月) 
8 ) (株)東芝技術資料「YAG レーザー」(1987 年 2 月)

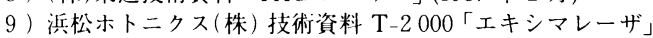
(1987 年 6 月)

10）村原证隆: 塑性と加I，，27 (1986), p. 934

11) R. Srinivasan: Laser Processing and Diagnostics, Springer Series in Chemical Physics, 39 (1984), p. 343 [Springer-Verlag]

$12) S$. Sato, $K$. Takahashi, $H$. Saito, $M$. Sugimoto and $T$. Fujioka: Proc. of ICALEO '88, Santa Clara, USA (1988 年 10 月)

13）池田证幸: 機械技術, 31 (1983) 4, p. 10

14 ) E. Beyer, G. Herziger and Ch. Höllt: Proc. of 2 nd Intern. Conf. on Beam Technology, Essen (1985 年 9 月)

$15)$ A. S. Kaye, $A$. G. Delph, $E$. Hanley and $C$. J. Nicholson: UKAEA Culham Laboratory 技術資料, CLM-P705 (1983)

16）沓名宗春: 実務展望 (1988) 126, p. 3

$17) H$. Sasaki, $N$. Nishiyama, $A$. Kamada, $E$. Yanagishima, $K$. Furukawa, T. Yoshimoto and $S$. Taniguchi: Proc. of $3 \mathrm{rd}$ CIS-FFEL, Lyon, France (1983 年 9 月)

18) $Y$. Inai, $N$. Okumura and 0 . Miyata: Proc. of LAMP '87, Osaka (1987 年 5 月), p. 517

$19)$ G. J. A. M. NotenвoOm: Laser (1984), p. 36 [The Welding Institute]

20） C. M. Sharp: Proc. of LAMP '87, Osaka (1987 年 5 月), p. 541

21) J.- L. Boutes and L. Micoulet: Proc. of 4 th CISFFEL Cannes (1988 年 9 月), p. 459

22) G. Cai, G. Ghiringhello, G. Perotti and A. Chiasera: Proc. of 4 th CISFFEL, Cannes (1988 年 9 月), p. 377

23) $V$. Ram, $E$. Tsory, $G$. KoHn and $A$. Stern: Proc. of 4 th CISFFEL, Cannes (1988 年 9 月), p. 451

24) M. ConTRE: Proc. of LAMP '87, Osaka (1987 年 5 月), p. 129

25) E. A. Metzbower, $P . E$. Denney, $F . W$. Fraser and $D . W$. MooN: Weld. J., 63 (1984) 7, p. 39

26) $M$. N. Watson and $C$. J. Dawes: Metal Construction, 17 (1985), p. 561

27) I. J. Stares, R. L. Apps, J. H. P. C. MegaW and J. SPURRIER: Metal Construction, 19 (1987), p. 123

28) E. M. Breinan and C. M. Banas: WRC Bulletin NO. 201, Arctic Pineline Steel (1975), p. 47

29) I. Masumoto, M. Kutsuna and C. Z. Xiao: Proc. of JOM-3, Helsinger (1986 年 12 月), p. 256

30) W. Wadiel.,$N$. T. Williams and $A . B$. Habertield: Metal Construction, 19 (1987), p. 313

31）山内信幸，三浦 実，高祖正志: 溶接学会全国大会講演概 要, 37 集 (1985), p. 298

32) S. Katayama and $A$. Matsunawa: Proc. of ICALEO, 44 (1984), p. 60

33) $R$. $K$. Holbert, Jr., T. M. Mustaleski and $L$. D. Frye: Weld. J., 66 (1987) 8, p. 21

34) P. A. A. Khan, T. Debroy and S. A. David: Weld. J., 67 (1988) 1, p. 1-s

35) A. C. Linginfelter: Proc. of LAMP '87, Osaka (1987 年 5 月), p. 211

36) M. J. Cifsi.AK, and P. W. FuerschBACH: Metall. Trans. B, 19 (1988), p. 319

37）益本 功, 沓名宗春, 鈴木純也: 溶接学会全国大会講演概 要, 37 集 (1985),p. 300

38) J. A. Mille. and J. Cheval.Ier: Weld. J., 62 (1983) 7, p. 49

39) W. Maocal, J. Zhujing and W. Weitao: Werkstoffe und Korrosion, 38 (1987), p. 124

40）荒木孝雄, 廣瀬明夫, 内原正人, 汇野 渉, 本多啓三, 近藤光昇: 溶接学会全国大会講演概要, 43 集 (1988), p. 132
41) 池田正幸: 溶接技術, 30 (1982) 8, p. 28

42) 丸尾 大, 宮本 勇, 片岡昌治, 荒田吉明: 溶接学会全国大 会講演概要, 35 集 (1984), p. 82

43）中西伸介, 市古修身, 浜田直也, 南田勝宏, 水橋伸雄, 芳賀博世: 溶接学会全国大会講演概要, 43 集 (1988) p. 290

44）産報出版編集部: 溶接技術, 33 (1985) 8, p. 40

45）三浦 宏: 溶接技術, 35 (1987) 8, p. 81

46) 土屋 均: 溶接技術, 36 (1988) 10, p. 17

$47) S$. Nakahara, $M$. Takaoka, $S$. Hishada, $T$. Fujita and $K$. Sugihara: Proc. of LAMP '87, Osaka (1987 年 5 月), p. 231

48) 安村幹明: 溶接技術, 35 (1987) 8, p. 76

49) 高橋久志: 機械技術, 35 (1987) 14, p. 62

50）安田耕三: 最近のレーザー加工技術に関する講習会テキス 卜 (日本溶接協会 HPL 委員会編) (1986), p. 13

51 ) I. DECKeR, J. RUGE and Y.-H. HAN: Schweissen und Schneiden, 37 (1985), p. 356

52）西川和一, 大東達哉: NEW WELTEC, 4 (1988) 10, p. 29

53) I. DeckeR and J. RugE: Proc. of 2 nd Intern. Conf. on Beam Technology, Essen (1985 年 9 月), p. 85

54 ）益本 功, 沓名宗春, 市川和利: 溶接学会全国大会講演概 要, 42 集 (1988), p. 270

55）木谷 基, 金岡 優, 柴山耕三郎, 吉田寿男: 三菱電機技 報, 61 (1987), p. 468

56) M. Moriyasu, S. Hiramoto: Proc. of ICALEO (1985), p. 129

57) 原田章二, 浦井直樹: 溶接技術, 36 (1988) 11, p. 68

58）浜崎正信, 勝村宗英, 内海明博: 高温学会誌, 11 (1985), p. 226

59）関 宏次, 森井 泰, 小林伸吾, 中井知章: 溶接学会全国大 会講演概要, 41 集 (1987), p. 340

60) 北側彰一: 最近のレーザ加工技術に関する講習会テキスト (日本溶接協会 HPL 委員会編) (1986), p. 27

61）アマダ(株)技術カタログ, The Laser Robot

62) B. S. WeIL: Proc. of LAMP '87, Osaka (1987 年 5 月), p. 145

63) S. Sato, $K$. Takahashi, $H$. Saito, $M$. Sugimoto, $T$. Fujoka, $S$. Shono, $O$. Matsumoto, $S$. Beppu and $K$. Matsuda: Proc. of ICALEO '88, Santa Clara (1988 年 11 月)

64) T. Znotins, D. Poulin and J. Reid: Proc. of LAMP '87, Osaka (1987 年 5 月), p. 581

65）山田明孝, 今井信一, 石川 憲: 東芝レビュー, 42 (1987) 7, p. 1

66）吉川省吾: 塑性と加工, 27 (1986), p. 928

67) I. Spalding: Proc. Instn. Mech. Engrs., 201 (1987) B3, p. 165

68) 溶接新聞 (昭和 63 年 10 月 17 日号),p. 16

69) 藤岡康朝: 自動化技術, 18 (1986) 11, p. 60

70) 安田耕三: 溶接学会全国大会講演概要, 40 集 (1987), p. 21

71) Y. Asaka, $H$. Kobayashi, S. ARita: Proc. of LAMP '87, Osaka (1987 年 5 月), p. 555

72) K. Shibata: Seminar Handbook on Applications of Laser Proc. in Automobile Fab. and Related Industries, Cambridge (1987 年 12 月)

73) P. A. Molian: Surface Engineering, 2 (1986), p. 19

74) J. R. BRadley and S. Kim: Metall. Trans. A, 19 (1988), p. 2013

75 ) W.- B. Li, $K$. E. Eastering and $M . F$. Ashby: Acta Metall., 34 (1986), p. 1533

76) P. A. Molian: J. Eng. Materials and Tech., 109 (1987), p. 179

77) C. H. Chen, C. P. Ju and J. M. RigsbeE: Mater. Sci. Technol., 4 (1988), p. 161 
78) J. Com-Nougué, E. Kerrand, B. Gal.tand, M. Barral: Proc. of 4 th CISFFEL (1988 年 9 月), p. 581

79) $H$. Kumakura, $K$. Togono, $K$. Tachikawa, $Y$. Yamada, S. Murase, M. Sasaki and E. Nakamura: Proc. of LAMP '87, Osaka (1987 年 5 月), p. 607

80) 益本 功, 篠田剧, 石山博之: 溶接学会全国大会講演概 要, 35 集 (1984), p. 112

81 ) 中尾嘉邦, 西本和俊: 溶接学会論文集, 5 (1987), p. 445

82 ) 益本 功, 沓名等春, 汐見一光: 溶接学会全国大会講演概 要, 41 集 (1987), p. 342

83) M. Fastow and M. Bamberger: Scr. Metall., 22 (1988), p. 183

84 ) 河内鳖輔, 森重徳男: 溶接学会全国大会講演概要, 43 集 (1988), p. 308

85 ) T. H. KIM and M. G. Suk: Proc. of LAMP'87 (1987 年 5 月), p. 413

86) E. W. Kreutz, $H . W$. Bifler, A. Gasser, $M$. Schwarz and K. Wissfinbach: Proc. of 4 th CISFFEL (1988 年 9 月), p. 635

$87) T$. Puig, J. L. Derep, G. Coquereiti.e and M. Condat: Proc. of 4 th CISFFEL (1988 年 9 月), p. 599

88) M. Pierantoni, J. D. Wagnifre and E. Bl.ank: Proc. of 4 th CISFFEL (1988 年 9 月), p. 681

89) C. W. Draper and C. A. Ewing: J. Mater. Sci., 19 (1984), p. 3815

90 ) I. MASUmoto and M. Kutsuna: ZIS Mitteilungen, 27 (1985), p. 239

91) 日本溶接協会特殊材料溶接研究委: 溶接技術, 36 (1988) 11, p. 111

92) 松縄 朗, 片山聖二, 政所康博: 溶接学会全国大会溝演概 要, 35 集 (1984), p. 120

93 ) 中毛嘉邦, 西本和俊, 上野文義, 葆祖正誌: 溶接学会溶接法 研究委具会資料, SW-1720-86 (1986)

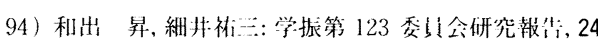
(1984) 2, p. 341

95) S. Dallaire and P. Cikio: Metall. Trans. B, 13 (1982), p. 479

96）川崎製鉄(株): 鐵, (1986) 134, p. 4

97) I. Masumoto and M. Kutsuna: Proc. of 4 th CISFFEL (1988 年 9 月), p. 399

98) C. H. Chen, C. J. Al.tstetter and J. M. Rigisief: Metall. trans. A, 15 (1984), p. 719

99) A. Matsunawa, S. Katayama, $Y$. Ohmi and T. Kuroki: Proc. of 4 th CISFFEL, Cannes (1988 年 9 月), p. 563

100）森田 毅, 平本誠威: NEW WELTEC, 4 (1988) 10, p. 41

101 ) 高藤英生, 市古修身: 鉄と鋼, 71 (1985), p. 1596

102 ) R. B. JaCKman and J. S. FoOri): J. Appl. Phys., 59 (1986), p. 2031

103) A. Gupta, G. A. West and K. W. Beeson: J. Appl. Phys. 58 (1985), p. 3573

104) A. Shintani: J. Appl. Phys., 61 (1987), p. 2365

105) 豊田浩一: 光学, 14 (1985), p. 256

106) A. Matsunawa and S. Katayama: Trans. JWRI, 14 (1985), p. 397

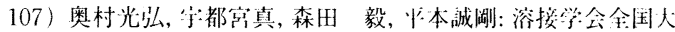
会講演概要, 42 集 (1988), p. 154

108）レーザ加厂技術実用マニアル(小林 睢編) (1987), p. 380 [新技術開発七ンター]

109) K. Masubuchi, I. Masumoto and Members of HPL Committee: Proc. of 2 nd Inter. Conf. on Beam Technology, Essen (1985 年 9 月), p. 20

110) Y. Namba: Proc. of LAMP '87, Osaka (1987 年 5 月), p. 601

111 ) 沓名宗春: 塑性と加I., 27 (1986), p. 949

112）尙多宗: 機械技術, 35 (1987) 14, p. 26

113）光産業技術张興協会: 溶接技術, 別冊 (1988), p. 58 